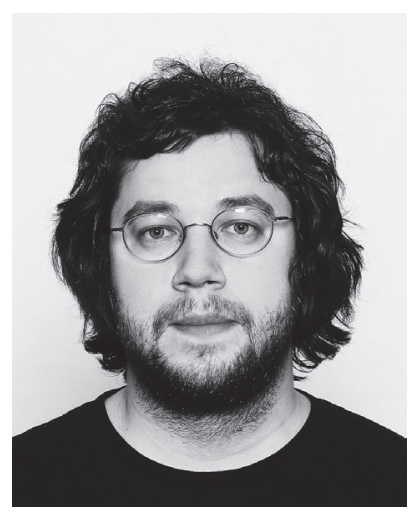

Roman Širouchov
Roman Širouchov - humanitarinių mokslų daktaras (05H), Vilniaus universiteto Istorijos fakulteto Archeologijos katedros mokslininkas-stažuotojas (podoktorantūros projektas); Klaipėdos universiteto Baltijos regiono istorijos ir archeologijos instituto lektorius.

Moksliniai interesai: vakarų baltų vèlyvojo geležies amžiaus archeologijos ir istorijos klausimai; X-XIII a. baltų ir Vakarų ir Rytų Europos kontaktų problemos; vakarų baltai Vokiečių ordino valstybès formavimosi procese; baltų etnogenezė, etnografija ir folkloras. El.paštas: ramans@prusai.org.

Roman Shiroukhov: Dr, Phd (05H), probationer scientist (post-doc project) of Department of Archaeology, History Faculty, Vilnius University; lecturer of Institut of Baltic Region History and Archaeology, Klaipeda University.

Research interests: Western Balts Late Iron Age Archaeology and History problems; $10^{\text {th }}-13^{\text {th }}$ centuries contacts of balts with West and East Europe regions questions; Western Balts in the genesis of Teutonic Order state; Ethnogenesis, ethnography and folklore of the Balts.

E-mail: ramans@prusai.org.

\title{
KURŠIŲ NERIJOS ANKSTYVŲJŲ VIDURAMŽIŲ ARCHEOLOGINIAI PAMINKLAI. KURŠIŲ IR PRÜSŲ KONTAKTŲ ZONOS KLAUSIMAS
}

\section{Anotacija}

Straipsnis skirtas XIII-XV a. Kuršių nerijos archeologinių paminklų tyrinėjimų rezultatams apibendrinti, pagrindinių radinių tipams analizuoti ir kuršiu ir prūsų genčių spejjamų kontaktų zonai nagrinèti. Apžvelgiamos ir revizuojamos nusistovejjusios paskutinio dešimtmečio teorijos, skirtos palikusiems XIII-XV a. Kuršių nerijos paminklus etnosams identifikuoti. Darbe pateikiama iki šiol neskelbta naujų tyrinejjimų ir archyvinė archeologinè medžiaga. PAGRINDINIAI ŽODŽIAI: prūsai, kuršiai, laidosena, etniniai indikatoriai.

\begin{abstract}
The paper is dedicated to the generalisation of the investigations results for the $13^{\text {th }}-15^{\text {th }}$ Curonian Spit archaeological sites, with the analyse of the main types of finds and supposed Prussian and Curonian contact zone problem. Last decade's established theories about the $13^{\text {th }}-15^{\text {th }}$ Curonian Spit archaeological sites populaton are also reviewed and revised. Unpublished till now new archaeological investigations and archival data is reflected in this study. KEY WORDS: Prussians, Curonians, burial rite, ethnic indicators.
\end{abstract}

DOI: http://dx.doi.org/10.15181/rh.v0i15.838

XI/XII-XV a. archeologiniai Kuršių nerijos paminklai tyrinètojų dèmesi patraukè jau nuo XIX a. antrojo trečdalio (1 pav., I.1 pried.). Visų pirma tai Stangenwalde kapinynas-senkapis (taip pat žinomas Kuncų pavadinimu), esantis apie $6 \mathrm{~km}$ į pietvakarius nuo Rybačij (Rossiten) kaimo. 
Roman Širouchov

Kuršių nerijos ankstyvųjų viduramžių archeologiniai paminklai.

110 Kuršių ir prūsų kontaktų zonos klausimas

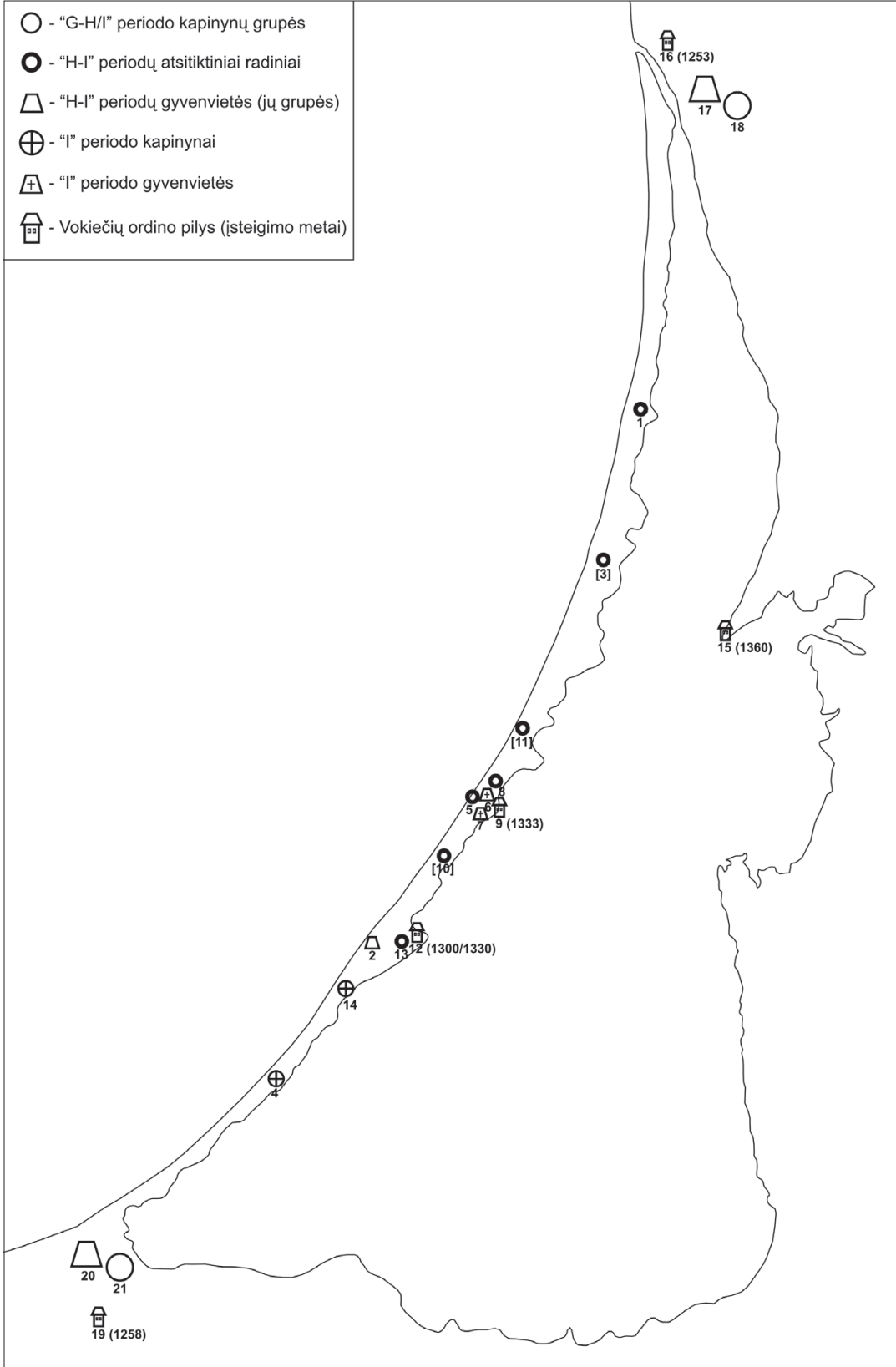

1 pav. Kuršių nerijos XII/XIII-XV a. archeologiniai paminklai ir atsitiktiniai radiniai (priedas I.1), autoriaus piešinys 


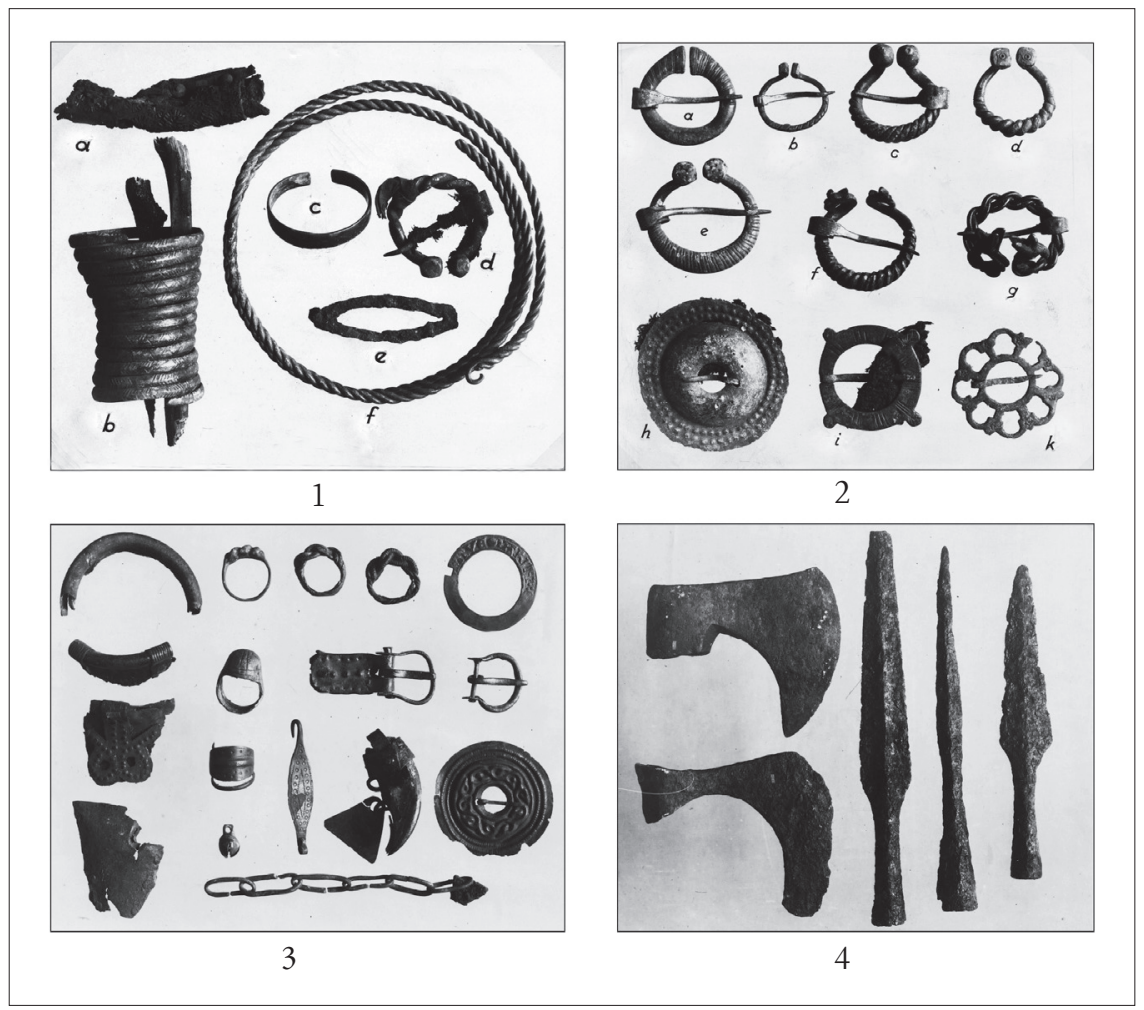

2 pav. XIII-XV a. Stangenwalde kapinyno radiniai:

papuošalai, buities įrankiai, ginklai (pagal CEN, RGA, T. 79)

Ji 1869-1870 m. tyrinèjo Paulius Schiefferdeckeris ir apie $1930 \mathrm{~m}$. Carlas Engelis (Schiefferdecker 1871, 45-49; 1873, 33-61; Hollack 1908, 83; Engel 1931, 108-118). Pagrindinès Stangenwalde įkapès priklauso jau Ordino laikotarpiui ir yra datuojamos XIII a. pabaiga - XV a. pradžia (2 pav.). Tai patvirtina artimiausios dirbinių analogijos iš 1992-2003 m. Anatolijaus Valujevo tyrinèto prūsų Alt-Wehlau (dab. Znamensko šiaurinis rajonas) nekropolio ir kitų prūsų, kuršių, žiemgalių ir sèlių XIII-XVI a. laidojimo paminklų (Odoj 1958, 152-154; Žulkus 1991, 21-25; Валуев 2003, 104-116; Griciuvienè 2005, 63-68, 180-213; 2007, 76-109; Griciuvienè, Grižas 2009, 394-420; Biermann et al. 2011) (3, 4 pav.). Kai kurių papuošalų atskiri tipai, publikuoti P. Schiefferdeckerio, gali būti datuojami ir anksčiau - XII-XIII/XIV a. Tai visu pirma susiję su pasagine sege sujungtais žvaigždiniais galais, kurių absoliuti dauguma 


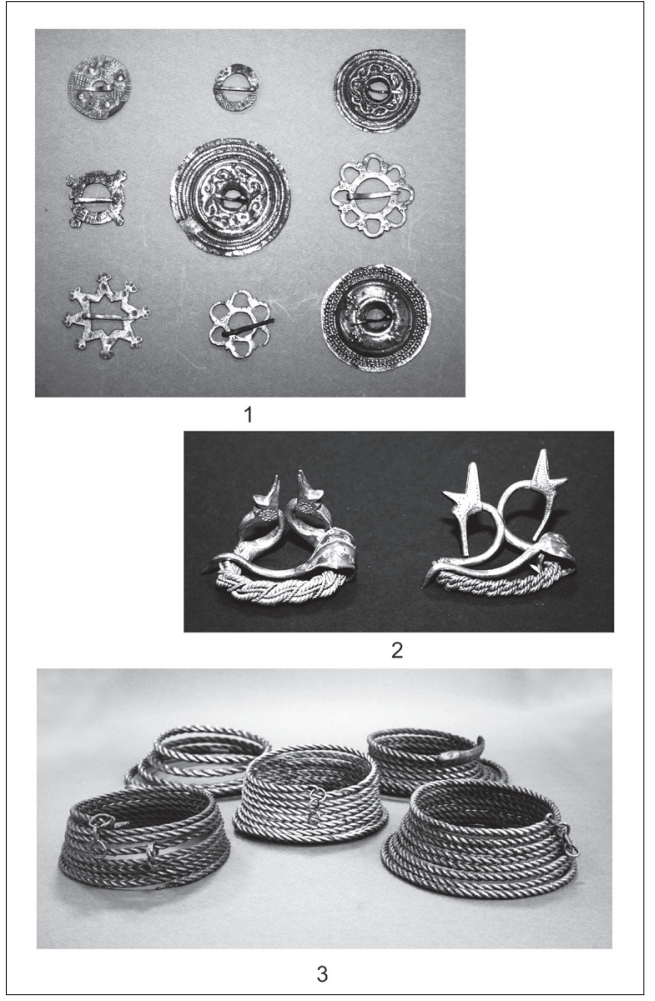

3 pav. XIII-XV a. Alt-Wehlau kapinyno radiniai: 1 . Plokštinès apskritos ir ažūrinès segès; 2. Pasaginès segès pintu lankeliu; 3. „Totenkrone“ tipo įvijinès antkaklès (КГОМ, N. Šal' nuotraukos)

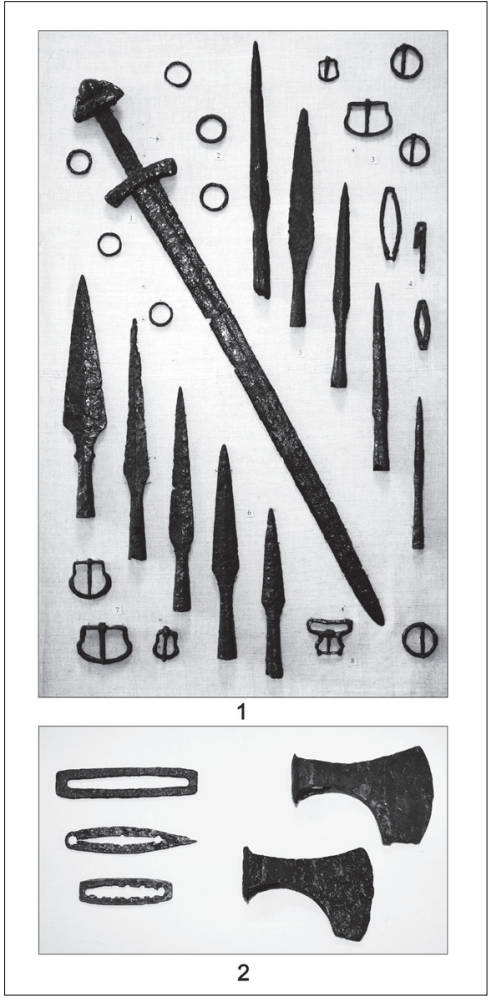

4 pav. XIII-XV a. Alt-Wehlau kapinyno radiniai: ginklai, diržų detalès, skiltuvai (КГОМ, N. Šal' nuotrauka)

aptinkama būtent prūsų areale (Širouchov 2012̌̌, 25-28, 12 pav.) (5 pav.), ir pasagine sege platėjančiais galais su spiralinių arba augalinių i̇vijų ornamentu (Schiefferdecker 1873, Taf. VI; Photographisches Album Berlin 1880, Taf. 16), analogiška rastoms prūsų Alt-Wehlau ir Widitten kapinynuose $^{1}$ (Kleemann 1956, Taf. XXIX; Валуев 2003, 111; Широухов 2011a, 176, Рис. 5.4-5) (6 pav.). Paskutiniuose moksliniuose tyrimuose Stangenwalde chronologija taip pat apribojama XIII-XV a. (Biermann

Panašaus ị prūsišką dekoro segès taip pat žinomos iš kuršių Pryšmančių-I (LNM EM 3, 4), Janiškių (Janischken) kapinynų ir Apuolès gyvenvietės, taip pat žiemgalių ir kitų Lietuvos rajonų, kur jos datuojamos nuo XII/XIII a. ir net iki XIV-XV a. sandūros (Širouchov 2012š, 31). 


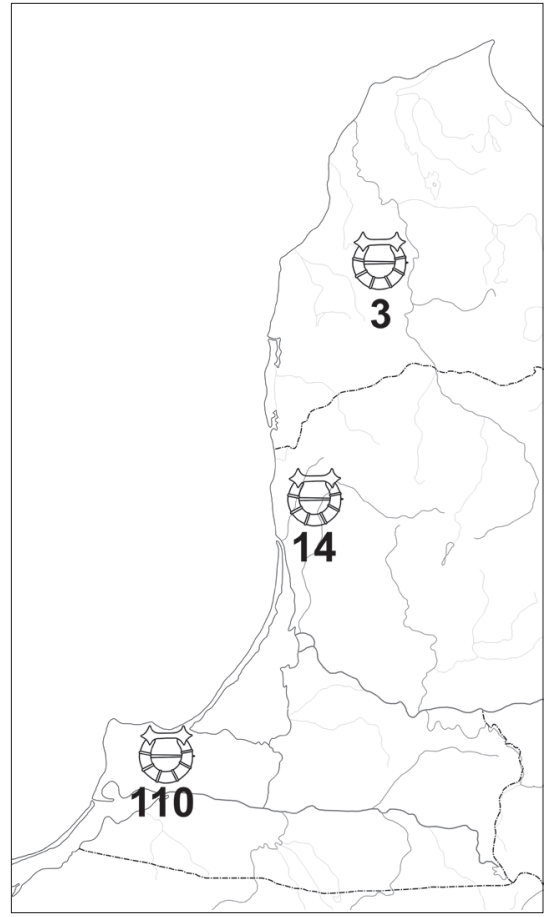

5 pav. Pasaginių segių sujungtais žvaigždiniais galais paplitimo prūsų ir kuršių arealuose schema (pagal Širouchov 2012š, 12 pav., II.3 pried.)

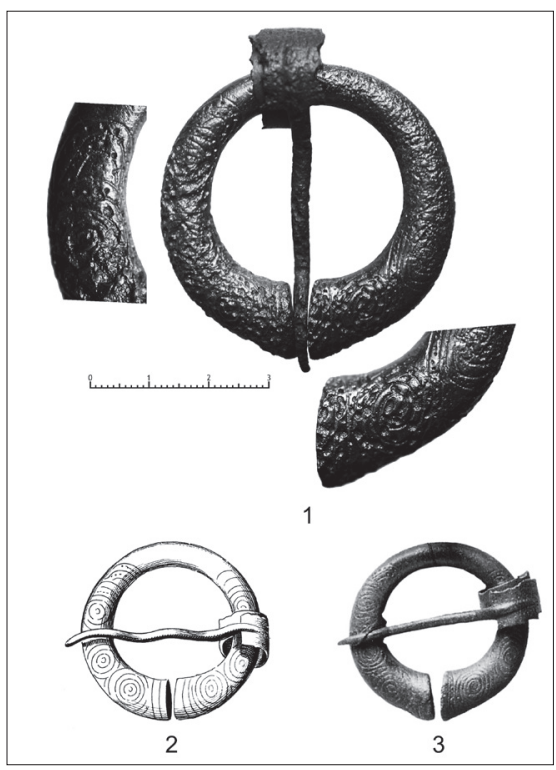

6 pav. XIII-XIV a. pasaginè segè paplatintais galais ir ,spiraliniu“ ornamanetu, Stangenwalde: 1. КГОМ 5007.122/PM, N. Šal' nuotrauka; 2. Schiefferdecker 1873, Taf. VI.16; 3. Photographisches Album Berlin 1880, Sect. I. Taf.16.781

et al. 2011, 277-278; Широухов 2011b, 193; Širouchov 2012š, 122), nors yra ir kitų Stangenwalde datavimo variantų - XI-XIV a. (Тюрин 2011, 128) bei XII-XIV a. (Кулаков et al. 2001, 46). Vis dèlto, kaip bus parodyta vèliau, pagal įkapes ir laidoseną šiame kapinyne pradèta laidoti XIII a. viduryje - antrojoje puseje ir tai susiję su tuo metu vykusiais istoriniais procesais: Vokiečių ordino inicijuota kolonizacija ir pačių prūsų pasaulèžiūros pakitimais. Sprendžiant iš įkapių ir P. Schiefferdeckerio kapų aprašymų, kapinynas buvo naudojamas visą XIV a. iki XV a. pradžiosvidurio (ar net vèliau?). Jo chronologija gali būti patikslinta tolesnių archyvinių ir galimų archeologinių tyrimų, nors spejjamo kapinyno vietos žvalgybos metu 2009 m. rugpjūtic ir 2010 m. sausi nepavyko aptikti kapinyno pėdsakų bei jo tiksliau lokalizuoti. ${ }^{2}$

2 Rudolfo Grenzo archyvo tome nr. 79 „Kr. Samland-Kurische Nehrung“ esančiame žemèlapyje, klaidingai priskirtame prie Stangenwalde, vaizduojamas kitas Ordino laiko- 
P. Schiefferdeckeris skyrè Stangenwalde kapinyną Baltijos jūros lyviams (venedams, o gal net šiaurès kuršiams?), kurie čia atvyko XIVXV a. (Schiefferdecker 1873, 65). Tai neturètų stebinti, nes iki 1870-ųjų panaši ì rastąią Stangenwalde kapinyne išsamiai publikuota medžiaga dauguma atveju priklausẻ būtent lyviu priešistorei ir ankstyvajai istorijai (Kruse 1842; Bähr 1850). C. Engelis tapatino Stangenwalde archeologinę medžiagą su kitomis prūsų ir skalvių „I“ laikotarpio (XIII a. antroji pusè - XIV/XV a.) kapinynų įkapemis: Gerdauen-Kinderhof, Lattenwalde, Splitter, Unterplehnen ir kt. (Engel 1931, 110; 1939, 46).

Vladimiro Kulakovo ir jo sekèju publikacijose Stangenwalde kapinynas priskiriamas kuršiams (Кулаков 1990, 22; Кулаков et al. 2001, 46; Тюрин 2011, 123-130). ${ }^{3}$ Šis teiginys, ypač turint omenyje tai, kad didžioji dalis Stangenwalde archyvinès medžiagos yra prieinama, o kapų ir daugumos įkapių aprašymai paskelbti, kelia abejonių. Juk kapinyne aptinkami tiek kuršiams, tiek prūsams būdingi medžiaginès kultūros ir laidosenos bruožai. Visi tyrinèti palaidojimai yra griautiniai kapai su šiaurès, šiaurès rytų, šiaurès vakarų ir pietryčių orientacija (Schiefferdecker 1871, 45-49; Hollack 1908, 83; Engel 1931, 108-118; Kulikauskas 1959, 85). Panašiai mirusieji orientuoti ir kituose prūsų XIII-XV a. nekropoliuose (Heym 1938š; Кулаков 1990, 21-22; Пронин et al. 2006, 335-336; Кулаков 2011, 92; Скворцов 2010, 32; Širouchovas 2011, 287). Iš dalies tai sutampa ir su Šiaurès Kuršo inhumacijų orientavimu (Muižnieks 2008, 46). Žinoma, kad Pietų Kuršo Pilsoto ir Mėguvos žemių gyventojai masiškai degino savo mirusiuosius jau 1050-1100 m. Atskiri griautiniai kapai Pietų Kurše egzistavo iki XII a. pradžios, o šiaurès ir šiaurès rytų kuršių areale, pasienyje su lyviais, žemaičiais ir žiemgaliais, kurie daugeliu atvejų savo mirusiuosius laidodavo nedegintus, atskiros kuršiu inhumacijos egzistavo iki XII-XIII a. sandūros, nekalbant apie XIII-XV a. griautinių kapu plitimą Šiaurès Kurše (Valatkienė 1995, 215-218; Žulkus 2004, 162; Muižnieks 2008, 43-49; Griciuvienè, Grižas 2009, 85, 209-212). Taigi, jei Stangenwalde inhumacijos teoriškai ir priklausytų pietų kuršiams, palikusiems Klaipedos rajono kapinynus ir gyvenvietes, tai dauguma įkapių turètų būti datuojamos vèliausiai XI/XII a. sandūra, o ne XIII-XV a. Ga-

tarpio paminklas, esantis pietineje Kuršių nerijos pusejje - Lattenwalde (dab. turistinès bazès „Diuny“ rajonas) (Širouchov 2012, 154).

3 Šiaurès Kuršo XIII-XVI a. tyrinètojas Vitolds Muižnieks taip pat skiria ši paminklą kuršiams (asmeninis susirašinėjimas žiemą 2011-2012 m.). 


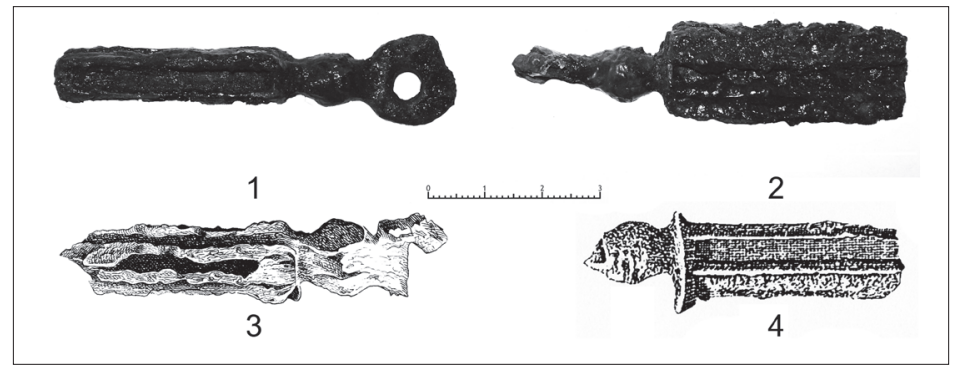

7 pav. Prūsų Ordino laikotarpio paminkluose rasti D-E tipų cilindrinių spynų raktai: 1, 2. Alt-Wehlau (КГОМ 16405.33, 16058.1, autoriaus nuotraukos); 3, 4. Stangenwalde (Schiefferdecker 1873: Taf. VII.17, 22)

lima spèti, kad dalis gyventoju i Kuršių neriją galèjo atvykti iš Pietų arba net iš Šiaurès Kuršo XIII a. pabaigoje - XIV a. Taip pat žinoma, kad prūsai XIII a. pabaigoje beveik atsisakè mirusiųuc deginimo papročio.

Aptariant Stangenwalde ikapes, parengtoje lenteleje palygintas svarbiausių juc tipu paplitimo prūsų ir kuršių žemėse intensyvumas XIII-XV a., vaizduojamas Stangenwalde kapinyno ìkapiu tipu paplitimas ir jų tipuc santykis prūsų ir kuršiu kultūriniuose arealuose (I.2 pried.). Kaip matyti iš minètos lentelès, dauguma Stangenwalde kapinyne aptiktų ikapių būdingos tiek prūsų, tiek kuršių

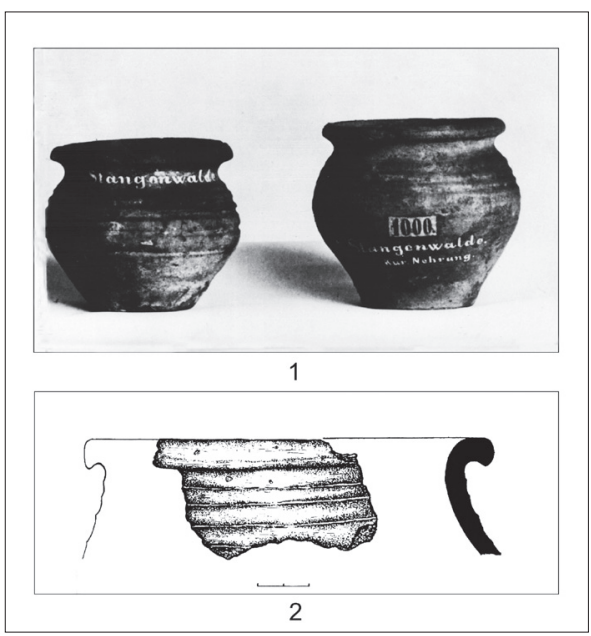

8 pav. XIV-XV a. „Ordino tipo“ pilkosios molio masės puodai ir jų fragmentai aptikti nekropolių teritorijoje: 1. Stangenwalde (CEN, Širouchovas 2011, 15.1 pav.); 2. AltWehlau (Валуев 1997š, рис.151.1) arealams XIII-XV a. Tiesa, daugelis jų akivaizdžiai dažniau aptinkamos prūsų kapinynuose. Tai pasaginès gyvulinès segès iš kelių vielų vytu lankeliu, skardinės segès, vytinės spiralinès antkaklès (,Totenkrone“), žiesti puodai, lokio nago kabučiai ir svarstyklès-svareliai, taip pat E-D tipų cilindrinių spynų raktai, diržų kabliukai ir diržai su sidabru inkrustuotais apkalais (2-3, 7-9 pav.). Dalis kitų ịka- 


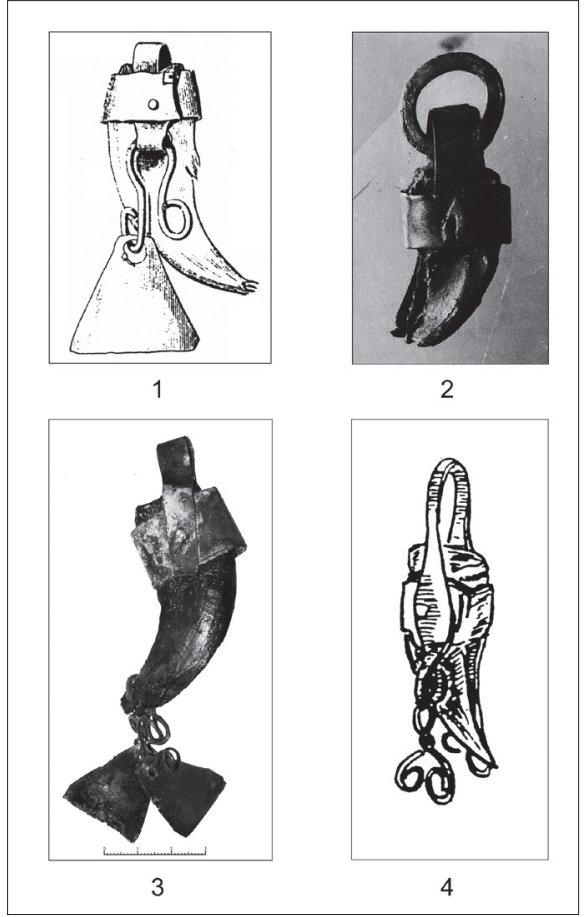

9 pav. Lokio nago kabučiai, aptikti prūsų (1?, 3), skalvių (2) ir pietų kuršių (4) XIII-XV a. nekropoliuose: 1. Stangenwalde (Schiefferdecker 1871: Taf. II.9; 2. Splitter (CEN); 3. Alt-Wehlau (КГОМ 16444.1, autoriaus nuotrauka); 4. Palanga (Žemaičių Kalnelis) (Žulkus 1991, Abb. 6)

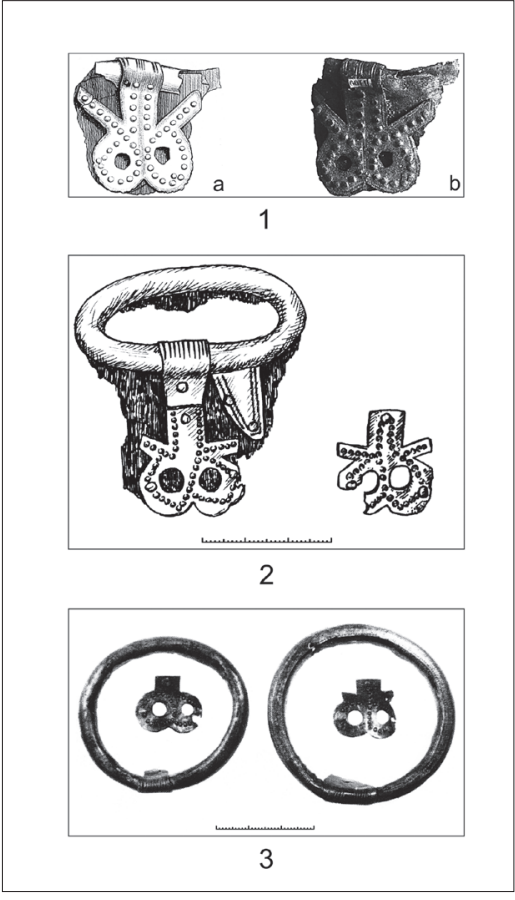

10 pav. Geriamojo rago apkalas iš Stangenwalde ir jo kuršiškos analogijos: 1. pagal Schiefferdecker 1871/1873; 2. Stangenwalde apkalas pagal CEN; 2. Alsungas Kalnini, kap. 20 (Bebre 2002, att. 21); 3. Griežè (Simniškytė 1998, 41 pav.)

pių yra būdingesnès kuršiams, bet tai daugiausia pavieniai dirbiniai: smiltainio verpstukai, spiralinès (ivvijinès) apyrankès, geriamojo rago apkalas (Schiefferdecker 1971; 1973; Engel 1931; Biermann et al. 2011; RGA; HJA) (10, 11 pav.). XI-XIV a. prūsų paminkluose iš tiesų dažniau aptinkami vietinès gamybos moliniai ir atvežtiniai šiferiniai verpstukai (Širouchov 2012̌̌, 50-51). Spiralinė apyrankẻ iš Stangenwalde iš dalies panaši ị rastąią kuršių Griežès kapinyne XII/XIII a. apyrankę (LNM AR 185, 527) ir kitas XI-XIII a. kuršiu kapinynuose aptiktas apyrankes. Nors kelios panašios 


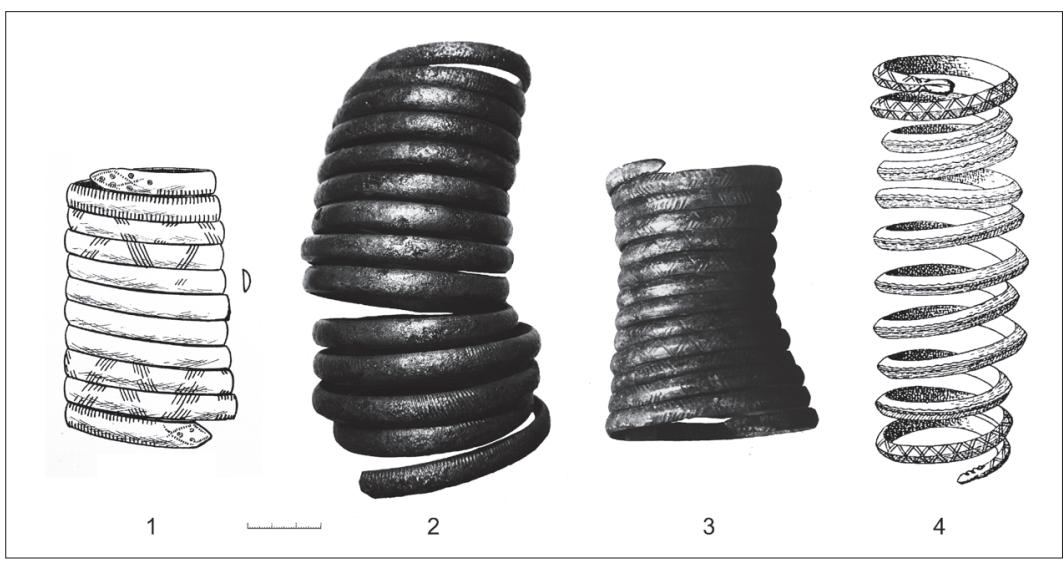

11 pav. İvijinès apyrankès, rastos kuršių teritorijoje ir Kuršių nerijoje:

1. Griežè (LNM AR 185:527); 2. Aukštkiemiai-Oberhof (?) (КГОМ/PM, autoriaus nuotrauka); 3. Stangenwalde, 29 kap.

(CEN); Juodkrantė (Scwarzort) (Gaerte 1929, 265f).

apyrankès žinomos ir prūsų teritorijoje (Blöcken, Viehof ir kt. kapinynai) (Širouchov 2012š, 39-40) (11 pav.). Prie kitų „kuršiškų“ Stangenwalde radinių galima priskirti geriamojo rago apkalą, turintị, kaip minėta, analogijas XII-XIII/XIV a. kuršių medžiagoje, o ypač - šiauriniame jų areale (Alsungas Kalnini, kap. nr. 20, LNVM A 11722, 37) (Simniškytė 1998; Bebre 2002) (10 pav.). Tai ligšiol vienintelis tokios formos ir dekoro apkalas, aptiktas Palangos-Klaipėdos-Kuršiu nerijos-Sembos pusiasalio regione. Tikètina, kad jis ị Kuršių neriją prekybiniais keliais pateko iš Šiaurès Kuršo jau vèliau, nei buvo laikoma (pagal šio tipo paplitimo laikotarpi). Gali būti, kad jị su savimi atsinešẻ jo savininkas, bet ị šị klausimą šiandien atsakyti sunku.

Kalbant apie vytines spiralines antkakles, kaip antai iš Stangenwalde kapų nr. 1 ar 2, galima pažymèti, kad jos pietinių kuršių kapinynuose aptinkamos dažniausiai iki XIII a. pradžios, o vẻliau jau beveik nebenaudojamos (Bliujienè 1999; Griciuvienè, Grižas 2009; Širouchov 2012š, 39-40). Spiralinès antkaklès, taip pat žinomos kaip „Totenkrone“, labai išpopuliarejjo tarp prūsų ir dažniausiai aptinkamos pasiturinčių moterų XIII a. antrosios pusès - XIV/XV a. inhumacijose: Alt-Wehlau, Gerdauen-Kinderhof, Równina Dolna ir kt. (3.3 pav.). Todèl Stangenwalde kapinyno antkaklès nėra tikslūs kuršių ar prūsų etninès priklausomybės rodikliai. Jos 
turi tik 2-3 spirales ir savo forma yra artimesnès X-XII/XIII a. pradžios Klaipėdos krašto vytinėms antkaklėms arba X-XII a. skalvių dirbiniams iš Linkūnų kapinyno (RGA; HJA). Bet aptiktųjų Stangenwalde antkaklių užbaigimai-kabliukai yra vèlyvos „degraduotos“ formos, būdingos prūsų XIII-XV a. antkakliu formoms. Taigi, Stangenwalde antkaklès yra gana archajiškos - jos galejjo priklausyti tiek ankstesniems laikotarpiams, tiek būti pagamintos, sekant senų dirbinių pavyzdžiais, ekonominès izoliacijos ar žaliavos trūkumo atveju. Nors dauguma rastų Stangenwalde dirbinių priklauso XIII/XIV-XV a., kaip antai pasaginès gyvulinės segės pintiniais lankeliais, Eugenijaus Svetiko I ir II tipų skardinės segės ir kt. (daugelis jų dažniau aptinkamos prūsų žemėse), kai kurių minètų radinių archajiškumas yra akivaizdus. Kitos segès su „Ave Maria“ užrašu arba žiedinès su 4 ataugomis aptinkamos tiek prūsų, tiek kuršių XIV-XV a. nekropoliuose, nors pirmųju atveju - gerokai dažniau. Kai kurie dirbiniai, pavyzdžiui, lokio nago kabučiai arba uždarieji skiltuvai, labiau žinomi prūsų ir skalvių paminkluose (9.2-3 pav.), nors tai veikiausiai atskleidžia tik nūdienos archeologinių šaltinių bazès padètị.

Taigi Stangenwalde kapinyne iš čia vyraujančių XIII/XIV-XV a. dirbinių, kurių dauguma buvo aptikta ir kituose šio laikotarpio prūsų nekropoliuose, išsiskiria keli archajinių bruožų dirbiniai, labiau būdingi XIIXIII a. pradžios kuršių medžiaginei kultūrai: tai 2-3 spiraliu antkaklès, ìvijinè apyrankẻ bei geriamojo rago apkalas. Taip pat šiame kapinyne aptikta pasaginè segè žvaigždiniais sujungtais galais, būdinga XI a. antrosios pusès - XII/XIII a. prūsų ir kuršių kultūroms. Tą patị galima sakyti apie kovos kirvị su atlenktais žemyn ašmenimis, kurie pasirodẻ kuršiu ir prūsų žemėse dẻl skandinavų įtakos Vikingų laikotarpiu ir plito daugiausia XIXII a. (2.4 pav.). İdomu tai, kad kapinyne nebuvo aptikta jokios žirgo arba raitelio aprangos, nors kape, kuriame rastas sidabru inkrustuotas „riterio“ diržas, turètų būti ir puošnūs pentinai, kaip Alt-Wehlau kapinyno atveju (Валуев, Кулаков 1999, 82-83). Beje, panašus diržas su puošniais sidabru inkrustuotais apkalais buvo aptiktas Simoniškių (Simonischken, Kr. Insterburg) kapinyne (Festschrift Insterburg 1905, Blatt XIV) (12 pav.).

Stangenwalde kapinyne tikriausiai buvo laidojami izoliuotos bendruomenès nariai, išlaikę kai kuriuos archajinius bruožus, veikiausiai perimtus iš pietų kuršių (archajinès antkaklès, įvijinè apyrankè, rago apkalas) arba sembų (pasaginė segė sujungtais žvaigždiniais galais) arealų XII a. pabai- 


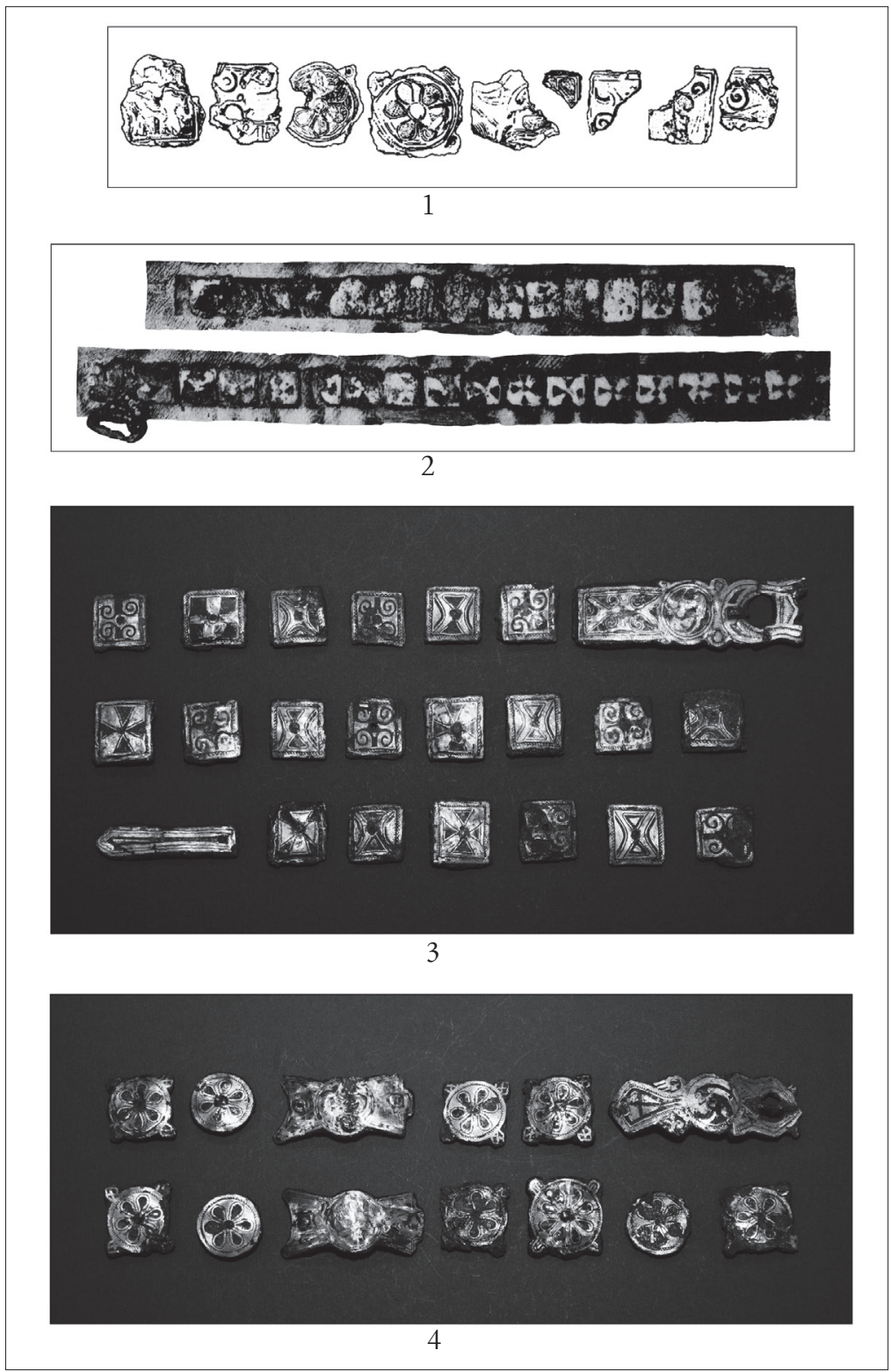

12 pav. XIII/XIV-XV a. vietinès gamybos (?) Vokiečių ordino riterių diržai, padengti sidabru, rasti prūsų griautiniuose kapuose: 1. Stangenwalde (Biermann 2011 et al., Taf. 19.5); 2 . Simonischken (Festschrift Insterburg 1905, Blatt XIV.27-28); 3,4. Alt-Wehlau (КГОМ 15914, 16404, N. Šal' nuotraukos) 
goje arba XIII a. pradžioje, t. y. iki Ordino ekspansijos, o galbūt net XIII a. viduryje per prūsų ir Ordino kovas, kuriose galejjo dalyvauti ir pietų kuršiai. Ankstyvesnių papuošalų ir kitų dirbinių, kaip paveldètų objektų ar ritualinių simbolių, dejjimas į vẻlyvesnius kapus žinomas ir kitų Baltijos jūros regiono teritorijų geležies amžiaus kapinynuose, pavyzdžiui, emaliuota IV a. pasaginė segė buvo aptikta VI a. degintiniame Hiidentöykkä (Suomija) kape (Wessman 2009, 77-78).

Manome, jog tai, kad Stangenwalde kapinynas yra Kuršių nerijoje, kuri net iki XX a. pradžios buvo gana uždara ir izoliuota nuo žemyno ir jo infrastruktūros (Strakauskaitė 2010, 54), viena vertus, lèmẻ kai kurių dirbinių, kurie jau nebebuvo populiarūs Sembos pusiasalyje ar Pilsote, formų išlikimą. Kita vertus, savo laidosena ir dauguma kitų įkapių kapinynas niekuo neišsiskiria iš kitų sembų, notangų, nadruvių, sūduvių, bartų, galindų ir skalviu Ordino laikotarpio nekropolių ir atskleidžia būtent šio regiono medžiaginę kultūrą, gyventojų etnosą ir ekonominius santykius (13 pav.).

Kaip buvo minèta, ankstesnio laikotarpio, t. y. XI-XII/XIII a., degintinių ar griautinių kapų (?) kapinyno teritorijoje kol kas neaptikta. Rudolfo Grenzo archyve (T. 79) yra Carlo Engelio padaryta nuotrauka su XI-XIII a. dirbiniais: Vb tipo kalavijo makščiu apkalas, pasagine segė ir apyrankès, R. Grenzo pažymėta kaip „Stangenwalde“. Po išsamios minètų dirbinių analizès pagal Wilhelmo Gaerte, Carlo Engelio, Berendto v.z. Můhleno ir kt. publikacijas ir Herbeto Jankuhno archyvą paaiškejjo, kad visi pateikti dirbiniai priklauso Kaup-Wiskiauten kapinynui. R. Grenzas, kaip „kabinetinis“ tyrèjas, galèjo supainioti ar neatpažinti pateiktus nuotraukoje dirbinius ir jų radimvietes (Širouchov 2012, 154) (14 pav.) .

Antras vėlyvojo geležies amžiaus archeologinis paminklas, esantis keli kilometrai i pietryčius nuo Rybačij (Rossittten) - Korallen-Berg gyvenvietė. Pirmą kartą jis buvo tyrinètas 1869 m. G. Berengto, Lovmejerio ir Vitticho, o 1870 m. - P. Schiefferdeckerio. 2001-2002 m. šio paminklo kasinejjimus pratęsė V. Kulakovas (Schiefferdecker 1873, 33-65; Hollack 1908, 83; Kulakov 2005, 175-181). Dar 2008 m. Eugenijus Tiurinas ištyré $12 \mathrm{~m}^{2}$ gyvenvietés plotą (Тюрин 2011, 123-131). P. Schiefferdeckeris

\footnotetext{
4 Ši klaida kartojasi ir kai kuriose naujose archeologinėse publikacijose, kaip antai: Archeologiczne dziedzictwo Prus Wschodnich w archiwum Feliksa Jakobsona. Das archäologische Vermächtnis Ostpreußens im Archiv des Felix Jakobson. Austrumprūsijas arheolog̊iskais mantojums Fēliksa Jākobsona arhīvā (Red. T. Nowakiewicz). Aestiorum Hereditas II. Warszawa: Ministerstwo Kultury i Dziedzictwa Narodowego, 2011.
} 
Roman Širouchov

Kuršiu nerijos ankstyvųių viduramžių archeologiniai paminklai.

Kuršių ir prūsų kontaktų zonos klausimas
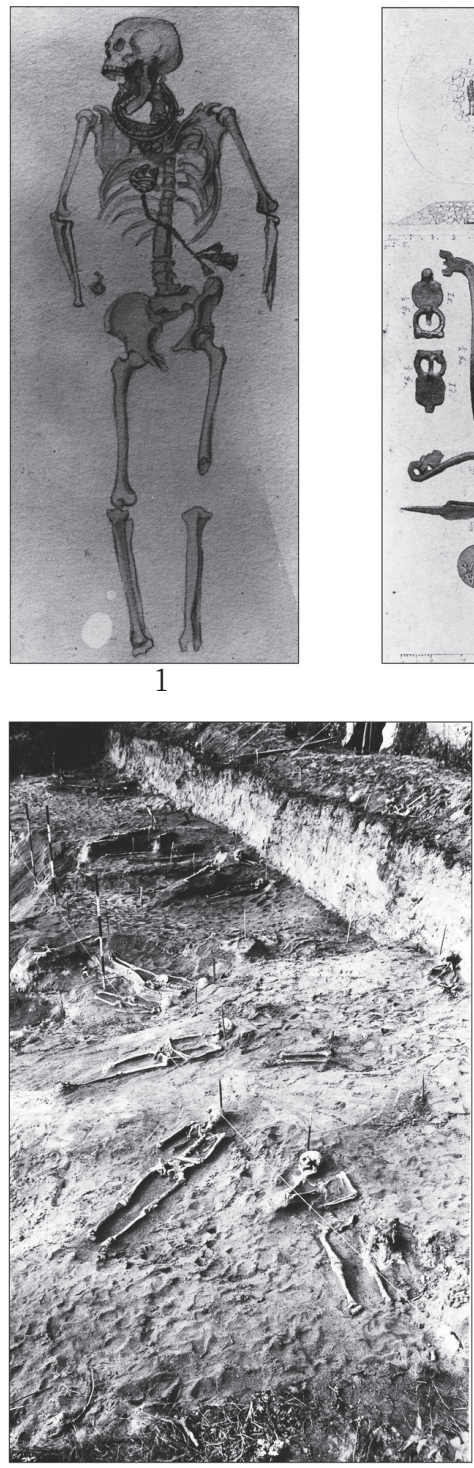

3
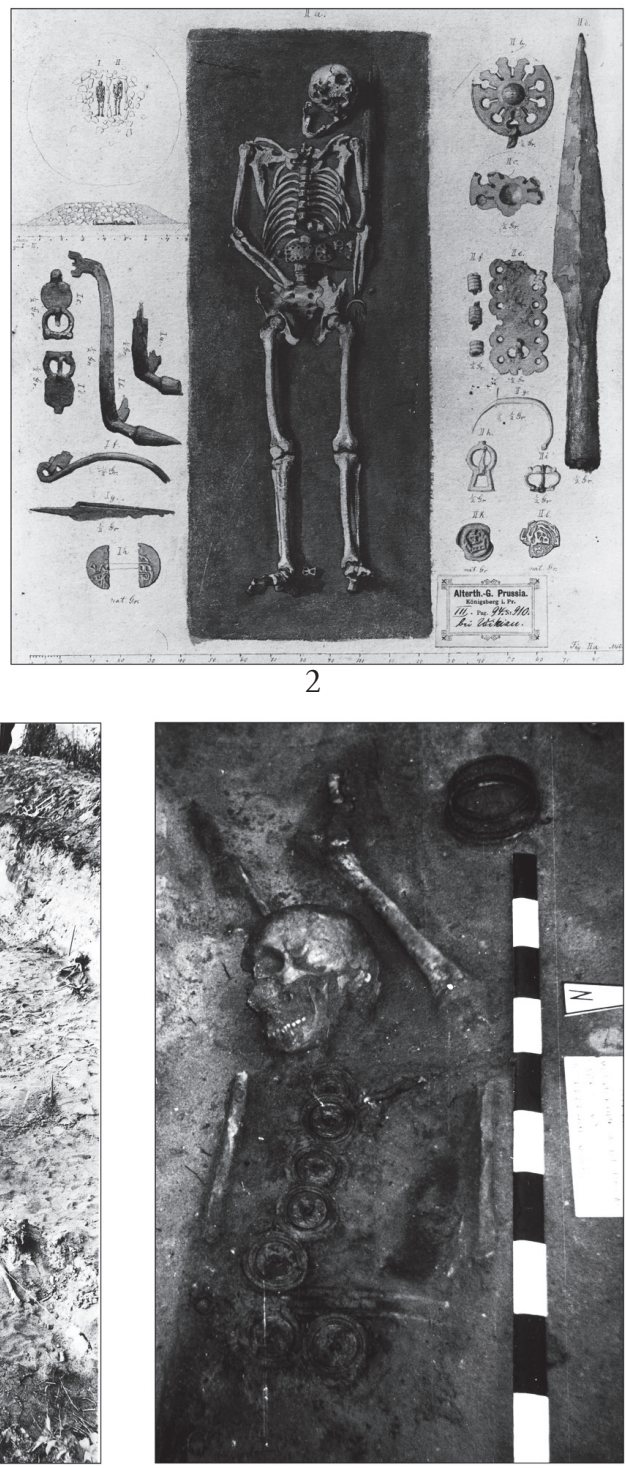

4

13. pav. XIII/XIV-XV a. prūsų griautiniai kapai: 1. Gerdauen-Kinderhof; 2. Kunterschtrauch; 3. Unterplehnen (Równina Dolna); 4. Alt-Wehlau, kap. 189 (1-3. RGA; 4. S. Koval nuotrauka) 
Roman Širouchov

Kuršių nerijos ankstyvųjų viduramžių archeologiniai paminklai.

128 Kuršių ir prūsų kontaktų zonos klausimas

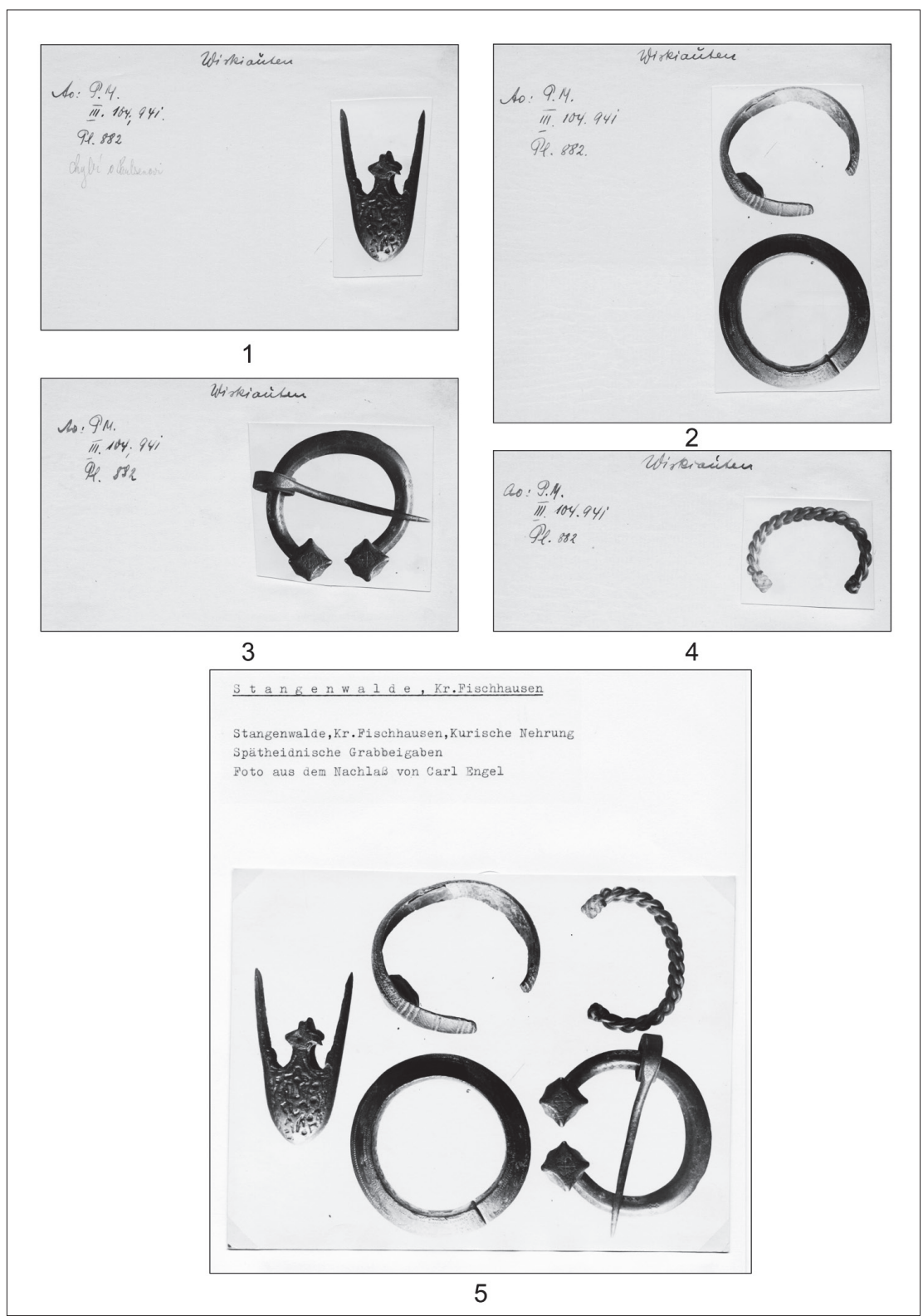

14 pav. Kaup-Wiskiauten kapinyno X/XI-XII a. radiniai, klaidingai priskirti R.Grenzo prie Stangenwalde: 1-4 (pagal HJA); 5. (RGA, T. 79) 
ir E. Hollackas preliminariai datavo paminklą $\mathrm{H}-\mathrm{J}$ periodais (XI-XIV a.) (Hollack 1908, 83), o V. Kulakovas ir E. Tiurinas - X-XI a. pradžia ir skiria ji kuršiams (Kulakov 2005, 175-181; Тюрин 2011, 123-127). Analizuodamas Korallen-Berg medžiagą, savo paskutiniuose darbuose šio straipsnio autorius linkęs ši paminklą datuoti XII-XIV/XV a. ir priskirti ji bendrai vakaru baltams (Широухов 2011a, 138; 2011b, 194-195; Širouchov 2012š, 124-126). Lyginamojoje lentelejje pateikiami svarbiausi Korallen-Berg rasti dirbiniai (I.3 pried.).

Taigi, pirminė V. Kulakovo publikuotu (Kulakov 2005; 2006; Кулаков 2008) ir buvusio Kuršių nerijos nacionalinio parko muziejaus kolekcijo$\mathrm{je}^{5}$ saugomų dirbinių analizè tikrai gali liudyti apie vẻlesnį nei X-XI a. paminklo datavimą. Pasaginès segès, rastos gyvenvietėje, atitinka vẻlyvus pasaginių segiu su cilindriniais ir aguoniniais galais potipius (15.2-4 pav.). Todèl pasaginè segè cilindriniais galais, stačiakampio skersmens ir lanku puoštu zigzago ornamentu gali priklausyti vèlyvoms tokių segių atmainoms (Volkaitė-Kulikauskienė1970, 161). Turint omenyje šios ir kitų segiu formą, konstrukciją ir dekorą bei kitų vèlyvų XIII-XV a. paminklų pasaginių ir žiedinių segių analogijas (kaip Alt-Wehlau ir Stangenwalde), jos gali būti datuotos XII/XIII-XIV а. (Валуев 2003, 111; Griciuvienè, Grižas 2009, 415; Svetikas 2009, 155-159, 168-169, 216-217; Biermann et al. 2011, Taf. 9-13; Широухов 2011a, 194). Be to, Korallen-Berge buvo aptikta plokštinė kryžminè segè su jau stilizuotomis (stačiakampio formos) ataugomis, pagaminta iš plonos skardos. Kaip minèta, pagal konstrukciją ir formą ši segè gali būti viena vèlyviausių iš aptiktų šio potipio kryžminių segių. Artimiausios jos analogijos rastos Palangos gyvenvietejje (Žulkus 2007, 352-353) ir atsitiktinai Sembos pusiasalyje ${ }^{6}$ bei Vakaru Lietuvoje (Širouchov 2012š, 31-33 pav.). Abi kontekstinès segès tyrinètojų preliminariai datuojamos XII a. Dèl neaiškių Korallen-Berg kryžminès segès radimo aplinkybiu ji gali būti datuojama gana plačiai - XII-XIII/XIV a. Technologiškai artimas šiai segei dirbinys aptiktas Talsų Vilkumuižas ežere kartu su kitais XII-XIII a. papuošalais (Šturms 1936, 81-82, Att. 12, 12). Ēvalds Mugurēvičs taip pat pailgina plokštinių kryžminių segių datavimą iki XIII-XIV a. sandūros (Mugurēvičs 2008, Tab. XXVII.49) (15.1 pav.).

5 Nuo 2012 m. vasaros priskirta prie Kaliningrado istorijos ir meno muziejaus.

6 Viena aptiktų Šosejnoje kapinyne kryžminių segių taip pat yra artima rastajai KorallenBerge. 


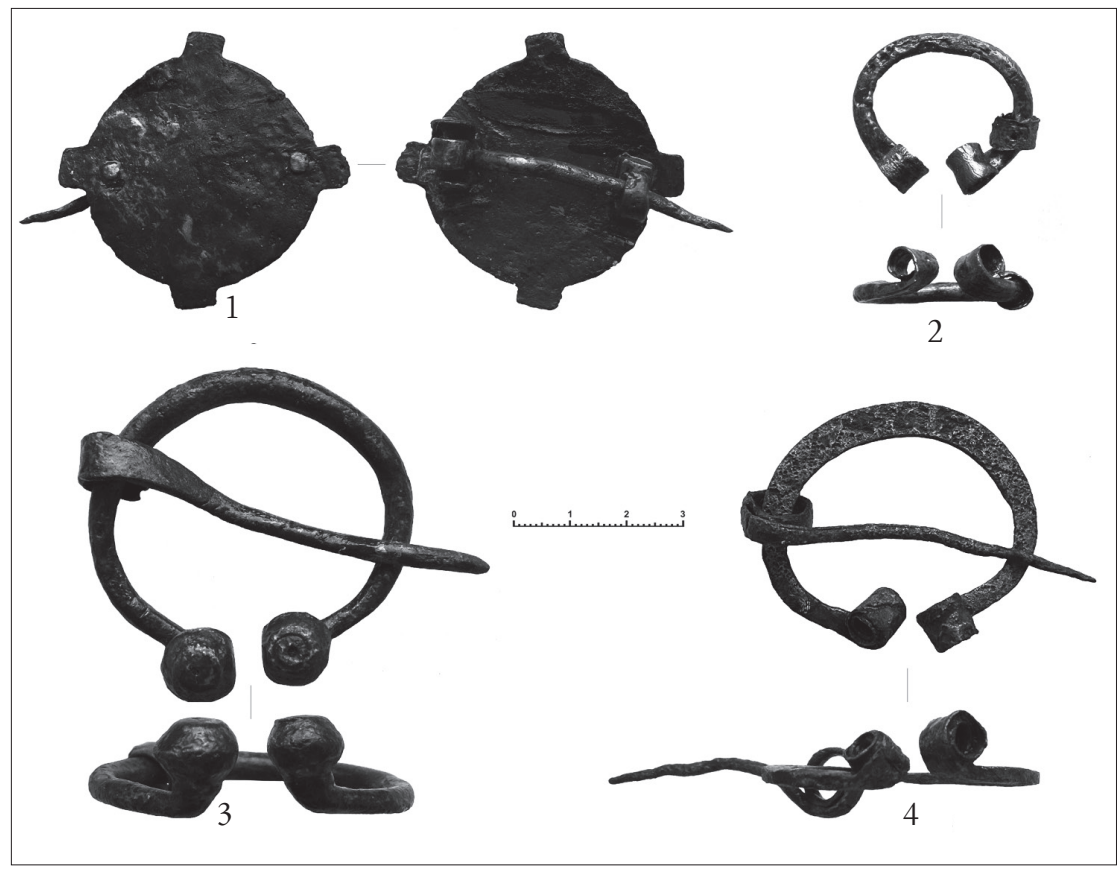

15 pav. Korallen-Berg gyvenvieteje rastos segès (Широухов 2011а, рис. 18)

Kalbant apie kitus radinius, aptiktus Korallen-Berg gyvenvieteje, reikia atkreipti dèmesị ir i̊ skiltuvą atriestais galais. Skiltuvai atriestais galais būdingiausia kuršių XI-XII/XIII a. įkapè. Nemažai jų buvo aptikta pietų kuršių kapinynuose: Apuolè $\dot{7}^{7}$ Aukštkiemiai-Oberhof, Bandužiai, Girkaliai $^{8}$, Gintarai, Griežè, Laiviai, Nausodis ${ }^{9}$, Palanga, Ramučiai ir kt. Skiltuvai taip pat randami kuršių gyvenvietėse ir piliakalniuose: Apuolè, Palanga (Birutès kalnas), Sabile, Talsi (Širouchov 2012̌̌, 42). Prūsų areale skiltuvai atriestais galais yra reti. Jie žinomi iš Klincovka-1 kapinyno kapų nr. 28 ir 68 (Кулаков 1999, 225, 240, рис. 15, 35) ir Seefeld kapinyno (HJA). Taigi, tikètina, kad šis skiltuvas ị Kuršių neriją pateko iš pietų kuršių arealo arba net iš pietų Skandinavijos ar rytinių kaimynų (16 pav.). 


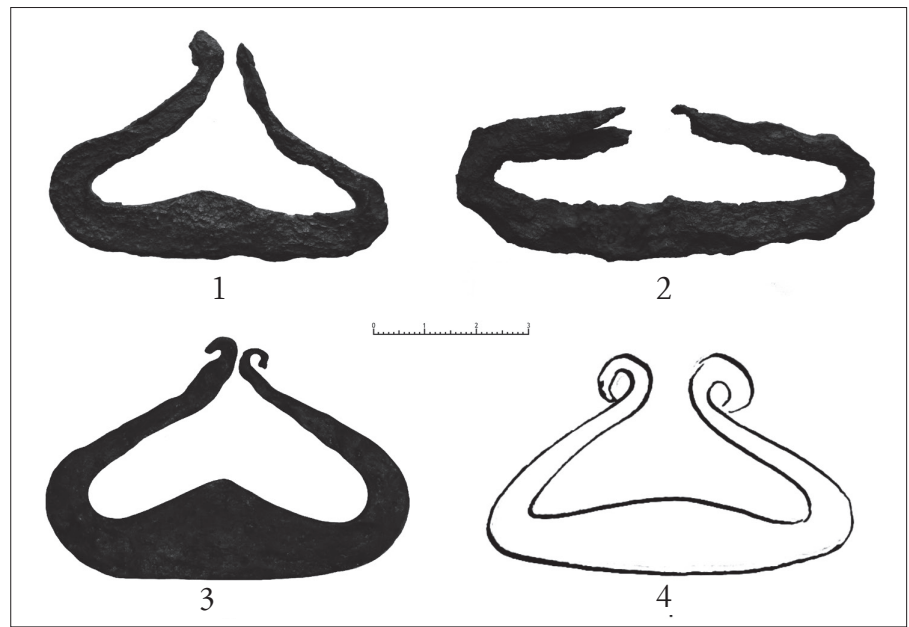

16 pav. Skiltuvai atriestais galais: 1, 2. Bandužiai (MLIM 48042; 47054, autoriaus nuotraukos); 3. Korallen-Berg (Широухов 2011b, рис. 7.5); 4. Seefeld (OPM 158/НJA)

Ittveriamieji žeberkliniai ietigaliai (arba žeberklai), kaip minèta, aptinkami tiek kuršių, tiek ir prūsų XI-XII/XIII a. degintiniuose kapuose ir rečiau gyvenvietėse. Prūsų areale jie rasti Alejka-3, Gerojskoje-5, Klincovka-1, Šosejnoje ir kituose paminkluose. Kuršių areale šie dirbiniai aptikti beveik visuose minèto laikotarpio kapinynuose: Griežès, Laivių, Palangos ir kt. (Širouchov 2012š, 125).

Korallen-Berge aptiktos laivų kniedès yra būdingos X-XII/XIII a. kuršių ir prūsų pajūrio gyvenvietèms, ị kurias jos tikriausiai patekdavo iš laivų medienos, panaudotos statybų darbams, arba kitos statybinès medžiagos: Gračevka (Kraam), Kaup-Wiskiauten/Wosegau (Mochovoje), Palanga (Birutès kalnas) (Гуревич 1960, 46.3; Žulkus 2007, 339-341; Ibsen 2009, Taf. 79). 2008 m. pirmą kartą Kuršių nerijoje buvo aptiktas šiferinis verpstukas (Тюрин 2011, 127, рис. 4), kurių absoliuti dauguma pietryčių Baltijos regione rasta Sembos pusiasalyje, iš kur šis verpstukas ir pateko i Korallen-Bergą arba tiesiogiai Nemuno prekybiniu keliu. Dèl nepakankamo gyvenvietės ištirtumo šis teiginys kol kas lieka tik prielaida.

Kalbant apie keraminius indus ir jų fragmentus, aptiktus Korallen-Berg gyvenvieteje, galima pažymėti, kad iš tiesų dauguma jų yra artimi žiestai 


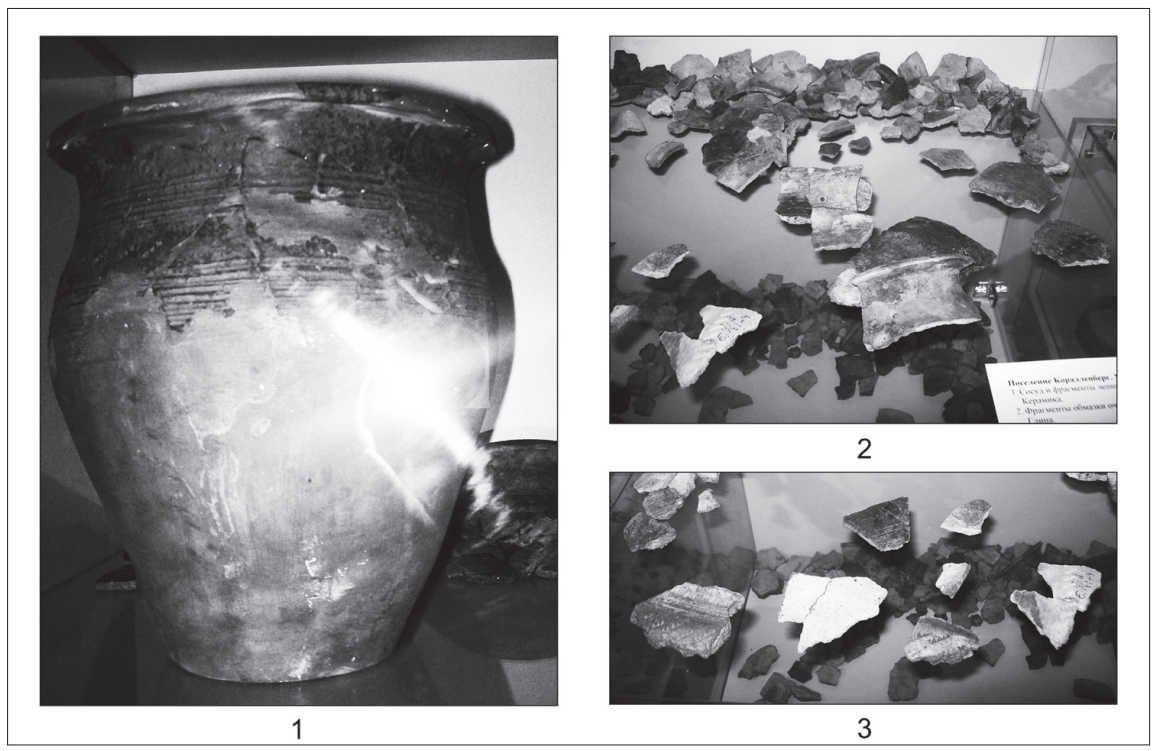

17 pav. Korallen-Berg gyvenvietès keramika (Kuršių nerijos nacionalinio parko muziejaus ekspozicija (МПНПКК), autoriaus nuotrauka)

keramikai iš pietų kuršių Palangos ir Žardès gyvenviečių ir pagal formas ir dekorą atitinka V. Žulkaus B1:a-b ir B2:b ir kai kuriuos kitus X/XIXII/XIII a. artimus puodų tipus (Kulakov 2005, 176-177; Žulkus 2007, 284-287; Kraniauskas 2011, 3 pav.). Taip pat jie yra panašūs arba identiški puodams ir jų fragmentams, aptiktiems sembų gyvenviečių kultūriniuose sluoksniuose: Gračevka, Kulikovo-8, Logvinovo (Guriewicz 1959, 212; Гуревич 1960, рис. 43; Кренке 2011š). Nenuostabu, kad žiesti puodai, aptikti Korallen-Berge, savo forma ir dekoru artimi pietų kuršių ir sembų kapinynų XI-XIII a. keramikai: Bandužiai, Girkaliai, Palanga, Ramučiai ir kt. (Stankus 1995; LNM AK; MLIM; RGA) ir Alejka-3, Bledau-II, Holmy, K1. Kaup, Klincovka-1, Laptau, Mitino, Schuditten, Schulstein ir kt. (Bezzenberger 1909, 50-53; 1914a, 1914b; Пронин et al. 2006, 230-289; Скворцов 2010, 134-135; Širouchovas 2011, 294-297; RGA, HJA). Taigi, Korallen-Berg keramika priklauso bendroms vakarų baltų arba „Baltijos jūros“ puodų formoms (pagrindinis - B2:b), atsiradusioms $\mathrm{X} / \mathrm{XI}$ a. dèl vakarų slavų ịtakos ir gyvavusioms iki XIII/XIV a. sandūros ir net vèliau (Bliujienè 2005, 158-162; Žulkus 2007, 321-323; Nowakiewicz, Wróblewski 2010, 515-519) (17 pav.). 
Ligšiol Korallen-Berg gyvenvietejje neaptikta ryškių Vikingų laikotarpio (X-XI a. pradžios) medžiaginès kultūros pėdsakų. Ankstyviausia jos egzistavimo riba gali būti XI/XII a. sandūra, nors veikiausiai šios gyvenvietės egzistavimo laikas sutampa su žemiausia Stangenwalde nekropolio egzistavimo riba - XIII a. Apie tai jau samprotavo Rytprūsių archeologai (Hollack 1908, 83; Engel 1931, 110, 115). Visas minètas Korallen-Berg radinių kompleksas datuojamas nuo XI/XII a. iki XIV a., nors hipotetiškai galima teigti, kad Stangenwalde kapinynas turèjo egzistuoti ir ilgiau, nes jis galejjo būti „susietas“ su Kuncų bažnyčia ir gyvenviete, galimu Rossiten kaimo bei pilies vystymusi ir veikla jau XIII/XIV-XV a.

Šiandien dar sunku kalbėti apie Stangenwalde kapinyno ir KorallenBerg gyvenvietės populiacijos etninę priklausomybę. Akivaizdu, kad besąlygiškas jų sutapatinimas su kuršiais (Kulakov 2005, 177; Тюрин 2011, 123-130) yra nepakankamai pagrịstas ir todèl klaidingas. Abiejų paminklų kultūriniuose sluoksniuose aptikti dirbiniai dažniausiai yra būdingi tiek sembų, tiek pietų kuršių kultūrai. Korallen-Berge šios proporcijos yra tolygios XI/XII-XIII/XIV a. dirbinių atžvilgiu, o Stangenwalde akivaizdžiai matyti, kad archajiškiausi dirbiniai priklauso tik kuršiams. Visa kita medžiaga yra būdingesne ir daug geriau žinoma iš prūsų Ordino laikotarpio nekropolių. Tai, kad visi kiti žinomi XIII-XV a. kapinynai ir gyvenvietės buvo aptikti tik pietinejje Kuršių nerijos dalyje, t. y. prūsų (sembų) pusẻje, dar kartą gali liudyti Stangenwalde kapinyno priklausomybę sembų palikuonims (1, 13 pav.). Galima konstatuoti, kad tik maža dalis dirbinių tikrai galejo patekti i Kuršių neriją iš Pietų Kuršo jūra ar sausuma. Tikriausiai XIII a. skirtumų tarp kuršių ir prūsų kultūrų jau buvo gerokai mažiau nei XI-XII a., o prasidejjus vokiečiuc kolonizacijai XIII a. antrojoje pusejje ir unifikuojant bendrą vakarų baltų kultūrą, šių skirtumų dar sumažejo.

Turint omenyje menką Kuršių nerijos geležies amžiaus paminklų ištirtumą, taip pat prūsų ir kuršių XI-XIII a. degintinių kapų čia trūkumą (šie kapai galbūt dar nèra aptikti), kyla klausimas, ar dalis dar XIII a. kuršių naudotų dirbinių kaip archajinès senienos ị Kuršiu neriją pateko XIV/ $\mathrm{XV}$ a. migracijų iš Šiaurès Kuršo metu. Tai mažai tikètina, bet vis dèlto ši teorija negali būti atmesta.

Kaip minèta, Kuršių nerijoje žinoma dar keletas atsitiktinių vẻlyvojo geležies amžiaus ir Ordino laikotarpio radinių, laikinų gyvenviečių bei kapinynų: Lattenwalde (tarp. Sarkau ir Stangenwalde), Liepas kalns prie 
Roman Širouchov

Kuršių nerijos ankstyvųjų viduramžių archeologiniai paminklai.

134 Kuršių ir prūsų kontaktų zonos klausimas

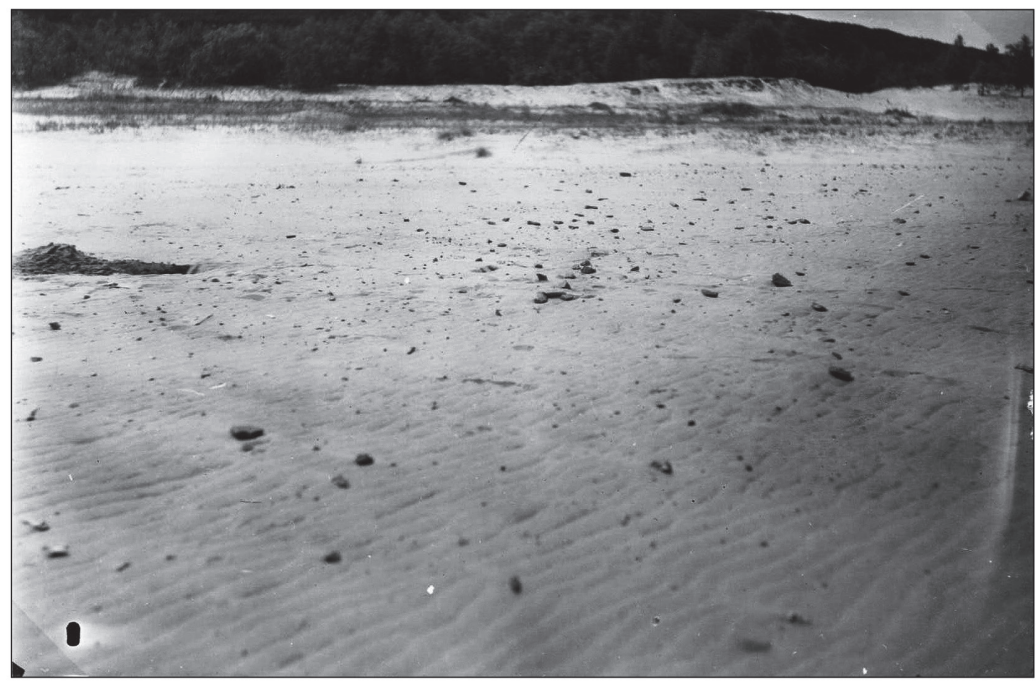

1

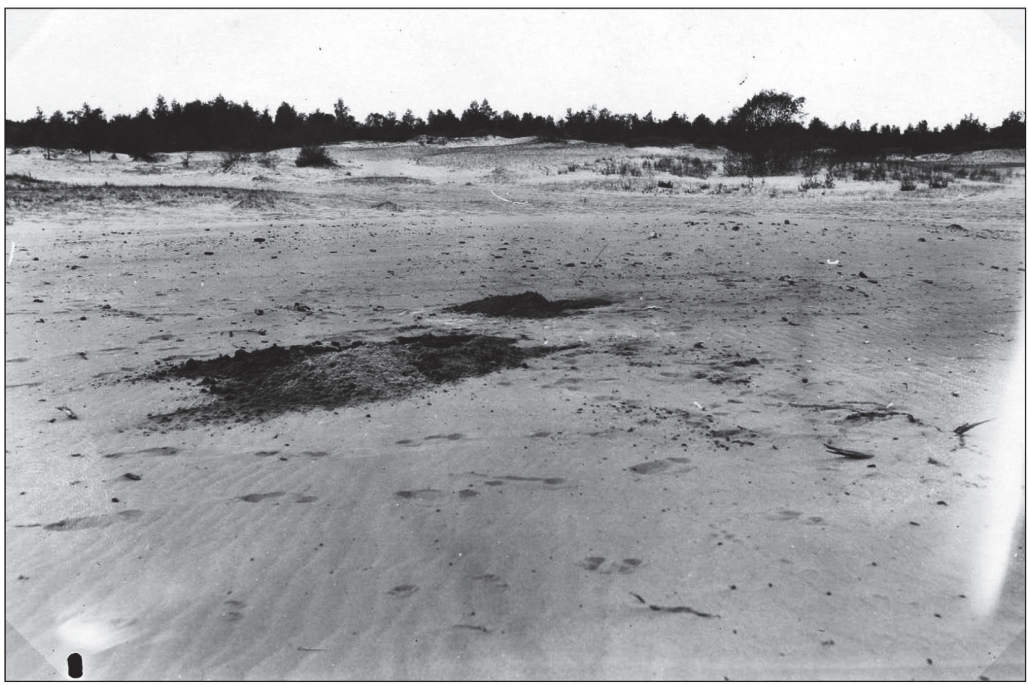

2

18 pav. Ordino laikotarpio (XIII a. antroji pusè - XV a. pradžia) Liepas-Kalns gyvenvietė prie Pilkupos (Pillkoppen/Morskoje) (1930 m. C. Engelio nuotraukos, RGA T. 78) 
Pilkupos (Morskoje) ir kt. (Engel 1931; Kulikauskas 1959; LAA 1978; Bliujiené 1999) (18 pav.). Reti radiniai, kaip antai svareliai, galbūt liudija apie tam tikrų vidinių arba net išorinių (jūrinių) prekybinių srautu - tikriausiai tarp Sembos ir Pilsoto - egzistavimą iki XIII a.

Visi žinomi kapinynai Kuršių nerijoje datuojami ne anksčiau nei XIII a. ir veikiausiai susiję su Ordino ekspansijos laikotarpiu, nors negalima paneigti kol kas nežinomų vidinių vakarų baltų tarpgentinių procesų. Tai netiesiogiai liudija visų gyvenviečių, atsiradusių čia iki XIII a., laikiną arba sezoninį-tranzitini pobūdị, apie ką jau spèliojo C. Engelis ir K. Forstreuteris (Engel 1931; Forstreuter 1981).

Kuršių nerijos, kaip intensyvaus prekybos ar tranzitinio kelio tarp sembų ir pietų kuršių iki XIII a., klausimas tebelieka atviras.

Sutrumpinimai

\section{Leidiniai}

AB - Archaeologia Baltica, Klaipèda (iki t. 6, 2006 - Vilnius)

AL - Archaeologia Lituana, Vilnius

LA - Lietuvos archeologija, Vilnius

Pr. - Sitzungberichte Altertumsgesselschaft „Prussia“/,Prussia“: Zeitschrift für Heimatkunde Königsberg

RO - Rocznik Olsztyński

SPÖG - Schriften der königlichen physikalisch-ökonomischer Gesselschaft zu Königsberg

МОАИ - Материалы охранных археологических исследований

\section{Archyvai}

CEN - Carl Engel Nachlass (im RGA), SHLSG

HJA - Herbert Jankuhn Archiv, SHLSG

RGA -Rudolf Grenz Archiv, SHLSG

Архив КОИХМ - Архив Калининградского областного историко-художественного музея

\section{Muziejai}

MLIM - Mažosios Lietuvos istorijos muziejus, Klaipėda

LNM - Lietuvos nacionalinis muziejus, Vilnius

PM (OPM) - Prussia Museum, Königsberg

КОИХМ (КГОМ) - Калининградский областной историко-художественный музей, Калининград

МПНПКК - Музей природы национального парка «Куршская Коса» 


\section{Šaltiniai}

Heym 1938š - Herbert Heym. Das Gräberfeld Zophen. Ein Beitrag zur Volks-und Kulturgeschichte des nördlischen ostpreußischen Binnenlandes vob 400 n. ztrw. bis zur Ordenszeit. Dissertation. In: Biblioteka Muzeum Archeologicznego w Poznaniu, nr. 9177.

Ibsen 2009š - Timo Ibsen. Etwa hier die Siedlung. Der fruhmittelalteriche Fundplatz Wiskiauten/Mohovoe in Kaliningrader Gebiet im Lichte alter Dokumente und neuer Forschungen. Dissertation zur Erlaung des Doktorg rades der Philosophischen Fakultät der Christian-Albrechts-Universität zu Kiel. Kiel.

Širouchov 2012š - Roman Širouchov. Prūsu ir kuršių kontaktai XI-XIII a. pradžioje archeologijos duomenimis. Daktaro disertacija. Humanitariniai mokslai, istorija (05H). Klaipèda, 2012.

Валуев 1997š - Анатолий Валуев. Альбом к отчёту по раскопкам грунтового могильника «Альт-Велау» у пос. Знаменск (Гвардейского района Калининградской области) Калининградским отрядом БАЭ в 1996 г. 1997. Архив КОИХМ. Дело № 62, 06.02.06-И.

Кренке 2011š - Николай Кренке. Отчёт Куликовского отряда Самбийской экспедиции о раскопках поселений Куликово 8, 8А, 8Б, 8В в Зеленоградском районе Калининградской области в 2010 г. Архив ИА РАН. Р. 1. Москва.

\section{Literatūra}

Bähr 1850 - Johann Bähr. Die Graber der Liven. Ein Beitrag zur Nordischen Alterthumskunde und Geschichte. Dresden.

Bebre 2002 - Viktorija Bebre. Dzeramie ragi Kuršu apbedījumos. Ventspila muzejas raksti, II, 96-118.

Bezzenberger 1909 - Adalbert Bezzenberger. Gräberfeld verschiedener Perioden bei Schuditten, Kr. Fischhausen. Pr., 22, 44-62.

Bezzenberger 1914a - Adalbert Bezzenberger. Gräberfeld bei Laptau. Pr., 23 (I), 157-180. Bezzenberger 1914b - Adalbert Bezzenberger. Gräberfeld bei Bludau, Kr. Fischhausen. Pr., 23 (I), 221-248.

Biermann et all. 2011 - Felix Biermann, Cecilia Hergheligiu, Heidrun Voigt, Marc Bentz, Ottilie Blum. Das Graberfeld des. 13. bis 15. Jahrhunderts Stangenwalde bei Rossitten auf der Kurischen Nehrung - Auswertung der Materialen im Berliner Bestand der Prussia-Sammlung (ehemals Königsberg/Ostpreußen). Acta Praehistorica et Archaeologica, 43, 215-345.

Bliujienė 1999 - Audronė Bliujienè. Vikingu epochos kuršiu papuošalų ornamentika. Vilnius: Diemedžio leidykla.

Bliujienè 2005 - Audronė Bliujienè. Pottery in Curonian cremation burials. Some aspects of interaction across the Baltic Sea in the Late Viking Age and Early Medieval Period. Culture and material Culture. Interarchaeologia, 1, 147-160.

Engel 1931 - Carl Engel. Zur Vorgeschichte der Kurischen Nehrung. Mannus, VIII, 99-121. Engel 1939 - Carl Engel. Die Bedeutung des Memellandes in vor- und frühgeschichtlicher Zeit Germanen Erbe (Leipzig), 5, 135-144.

Festschrift Insterburg 1905 - Festschrift zum 25 jährigen Jubiläum der Altertumsgesellschaft Insterburg (1880-1905), H. 9. Insterburg.

Forstreuter 1981 - Kurt Forstereiter. Wirkungen des Preussenlandes. Berlin. 
Gaerte 1929 - Wilhelm Gaerte. Urgeschichte Ostpreußens. Ostpreußische Landeskunde in Einzeldarstellungen. Königsberg: Gräfe und Unser.

Griciuvienè 2005 - Eglè Griciuvienè. Žiemgaliai. The Semigallians: Baltu archeologijos paroda. Katalogas. Vilnius: LNM, LNVM.

Griciuvienè 2007 - Eglè Griciuvienè. Seliai. The Selonians: Baltu archeologijos paroda. Katalogas. Vilnius: LNM, LNVM.

Griciuvienè, Grižas 2009 - Eglè Griciuvienè, Gytis Grižas. Kuršiai. Genties kultūra laidosenos duomenimis. The Curonians. Tribe Culture According to the Burial data: Baltu archeologijos paroda. Katalogas. Baltic Archaeological Exibition. Catalogue. Vilnius: LNM, LNVM.

Guriewicz 1959 - Frida Guriewicz. Nektóre dane o osadach i grodziskach Sambii. RO, II, 206-219.

Hollack 1908 - Emil Hollack. Erläuterungen zur vorgeschichtlichen Übersichtskarte von Ostpreußen. Berlin: Komissions-Verlag von Carl Flemming.

Kleemann 1956 - Otto Kleemann. Sämlandische Funde und die Frage der älsten Steigbügel in Europa.

Documenta archaeologica W. La Baume dedicata. Rhein. Forsch. Voregschichte. Bd. 5.

Kraniauskas 2011 - Rokas Kraniauskas. Kuršiu gyvenvietės Palangos dvaro sodybos teritorijoje. Archeologiniai tyrinejimai Lietuvoje 2010 m., 45-59.

Kruse 1842 - Friedrich Kruse. Necrolivonica. Altertühmer Liv,-, Esth-urlands bis zur Einführung der Christlichen Religion in den Kaiserlich Russischen Ostsee-Gouvernements. Dorpat.

Kulakov 2005 - Vladimir Kulakov. Siedlung Korallen-Berg. Kurze Nachricht über die Ausgrabungen 2001 und 2002. Res Balticae. Miscellanea Italiana di studi Baltistici. Vol. 10, Livorno, 175-182.

Kulakov 2006 - Vladimir Kulakov. Die Runen des Samlands: Funde Saison 2001. AB, 6, $152-157$.

Kulikauskas 1959 - Pranas Kulikauskas, 1959. Seniausieji Kuršių Neringos gyventojai. Iš lietuvių kultūros istorijos, II, Vilnius, 72-85.

LAA 1978 - Lietuvos TSR archeologijos atlasas, IV. Vilnius: Mokslas.

Mugurēvičs 2008 - Ēvalds Mugurēvičs. Viduslaiku ciems un pils Salaspils novadā. Rīga: Latvijas Vēstures institūta apgāds.

Muižnieks 2008 - Vitolds Muižnieks. 14., 15. gs. ugunskapi Kurzemē. In: Sud. V. MUIŽNIEKS. Pètījumi kuršu senatnē LVMR, 14, 35-56.

Nowakiewicz, Wróblewski 2010 - Tomasz Nowakiewicz, Wojciech Wróblewski. „Pruzzische“ und „slawische“ Keramik im fruhmittelalterlichen Galinden. In: Red. U. Lund Hansen, A. Bitner-Wróblewska. Worlds apart? Contacts across the Baltic Sea in the Iron Age. Kobenhavn-Warszawa, 505-524.

Odoj 1958 - Romuald Odoj. Sprawozdanie z prac wukopaliskowych przeprowadzonych w Równine Dolnej, pow. Ketrzyn. w 1956-57. RO, 1, 117-156.

Photographisches Album Berlin 1880 - Photographisches Album der Prähistorisches und Antropologisches ausstellung zu Berlin, I. Berlin.

Schiefferdecker 1871 - Paul Schiefferdecker. Der Begräbnisplatz bei Stangenwalde. SPÖG, $12,42-56$

Schiefferdecker 1873 - Paul Schiefferdecker. Bericht über eine Reise zur Durchforschung der Kurischen Nehrung archaeologischer Hinsicht. SPÖG, 14, 32-68. 
Simniškytė 1998 - Andra Simniškytè. Geriamieji ragai Lietuvoje. LA, 15, 185-245

Stankus 1995 - Jonas Stankus. Bandužiu kapinynas. Monografija. LA, 12, 1-156.

Strakauskaitė 2010 - Nijolè Strakauskaitè. Kultūros kraštovaizdis prie Kuršiu marių. Klaipèda: Klaipedos universiteto leidykla.

Svetikas 2009 - Eugenijus Svetikas. Lietuvos Didžiosios Kunigaikštystès christianizacija $X I V$ a. pab. $-X V$ a., t. 1. Vilnius: Diemedžio leidykla.

Širouchov 2012 - Roman Širouchov. „Prūsijos“ muziejaus archeologijos kolekcijos ir archyvai. Mažoji Lietuva: paribio kultūros tyrimai. Vilnius, 131-166.

Širouchovas 2011 - Romanas Širouchovas. Nauji prūsų X-XIII a. kapinynų tyrimai vakarų baltų kultūros kontekste. Lituanistica, 57, nr. 3 (85), 276-304.

Šturms 1936 - Eduards Šturms. Vilkumuižas ezera atradumi. Senatne un Māksla, II. Rīga, $72-86$.

Valatkienė 1995 - Laima Valatkienè. Kuršų senkapis. LA, 11, 214-243.

Volkaitè-Kulikauskienè 1970 - Regina Volkaitė-Kulikauskienè. Lietuviai IX-XII a. Vilnius: Mintis.

Wessman 2009 - Anna Wessman. Reclaiming the past: using old artefacts as a means ofremembering. Ats. red. A. Šne, A. Vasks, Memory, society, and material culture. Papers from the Third Theoretical Seminar of the Baltic Archaeologists (BASE) Held at the University of Latvia. October 5-6, 2007. Interarchaeologia, 3. Riga-Helsinki-TartuWilnius, 71-88.

Žulkus 1991 - Vladas Žulkus. Die Kuren im 13.-15. Jahrhundert. Prußen, Kuren und Masuren. Drei Beitrage zur Landeskunde Ostpreußens. Hamburg-Weißenburg: Braun\&Elbel, $15-29$.

Žulkus 2004 - Vladas Žulkus. Kuršiai Baltijos jūros erdvejje. Vilnius: Versus aureus.

Žulkus 2007 - Vladas Žulkus. Palanga in the middle ages. Ancient settlements. Vilnius: Versus aureus.

Валуев 2003 - Анатолий Валуев. Итоги изучения грунтового могильника Альт-Велау. Проблемы Балтийской археологии. Калининград: Издательство Калининградского государственного университета, 104-116.

Валуев, Кулаков 1999 - Анатолий Валуев, Владимир Кулаков. Тевтонский крест и бог Перкуно. Наука в России, 6. Москва, 80-85.

Гуревич 1960 - Фрида Гуревич. Из истории Юго-Восточной Прибалтики в I тысячелетии н.э. (по материалам Калининградской области). Отдельный оттиск. In: Древности Северо-Западных областей РСФСР в I тысячелетии н.э. Материальь и исследования по археологии СССР, № 76. Москва-Ленинград: Издательство Академии Наук СССР.

Кулаков 1990 - Владимир Кулаков. Древности Пруссов VI-XIII вв. Археология СССР. Г1-9. Москва: Наука.

Кулаков 1999 - Владимир Кулаков. Ирзекапинис. Stratum Plus, 5. Санкт-ПетербургКишинёв-Одесса, 211-273.

Кулаков 2008 - Владимир Кулаков. Вторая волна заселения: скандинавы и западные балты. In: Куршская Коса. Культурный ландшафт. Калининград, 2008, 40-65.

Кулаков et al. 2001 - В. И. Кулаков, Т. Н. Тепляков, Г. С. Пузакова. Остров Розитmen: история заселения. Калининград.

Кулаков 2011 - Владимир Кулаков. Балтская часть могильника Кауп. $A L, 12,87-98$. 
Пронин et al. 2006 - Г. Н. Пронин, М. Е. Смирнова, Т. Н. Мишина, В. В. Новиков. Могильник Поваровка X-XIII вв. (Калининградская область). МОАИ, 8. Москва: Tayc.

Скворцов 2010 - Могильник Митино V-XIV вв. (Калининградская область) по результатам исследований 2008 г., т. 1. МОАИ, 15. Москва.

Тюрин 2011 - Евгений Тюрин. Кауп и Кораллен-берг в финальной стадии эпохи викингов. Культурное наследие Восточной Пруссии, II. Калининград: Издательсво БФУ им. И. Канта, 123-132.

Широухов 2011a - Роман Широухов. Контакты пруссов и куршей X-XIII вв. по археологическим источникам. $L A, 37,167-206$.

Широухов 2011b - Роман Широухов. К вопросу об отношениях пруссов и куршей в X-XIII вв. Введение в проблематикую. Культурное наследие Восточной Пруссии,

II. Калининград: Издательсво БФУ им. И. Канта, 133-145.

\section{Roman Shiroukhov}

\section{EARLY MEDIEVAL ARCHAEOLOGICAL SITES OF THE CURONIAN SPIT. THE QUESTION OF THE CONTACT ZONE FOR PRUSSIANS AND CURONIANS}

Summary

The article is dedicated to the archaeological monuments investigated on the Curonian Spit from the very beginning of archeological excavations here in the 1869 up to the 2008. All investigated archaeological monuments are located in the Southern part of Curonian Spit and are dated by the $13^{\text {th }}-15^{\text {th }}$ centuries in case of Stangenwalde cemetery and by the $12 / 13^{\text {th }}-14^{\text {th }}$ centuries for Korallen-Berg settlement. Materials of Stangenwalde inhumation graves have a wide range of parallels and analogies with Prussian cemeteries of the Teutonic Order period as Alt-Wehlau, Gerdauen-Kinderhof, Mitino, Równina Dolna etc. Some archaic artefacts as penannular brooch with connected star-shaped terminals and also spiral bracelet and drinking horn mount of Curonian types could appear here far behind the date of their production, from areas of Sambia and today's Klaipeda district respectively. Perhaps, it is the same case for oval steels with up-twisted terminals, found in Korallen-Berg. The forms of ceramics and ornaments occurred in Korallen-Berg have the number of analogies both in cemeteries and settlements of the $12^{\text {th }}-14^{\text {th }}$ centuries in Prussian and Curonian area. The fact that Prussian or Curonians cremation graves 
of the $11^{\text {th }}-13^{\text {th }}$ centuries did not occur in Curonian Spit, together with the data of mentioned monuments, as well as stray finds of ornaments of the $12 / 13^{\text {th }}-15^{\text {th }}$ centuries in the area of former Rossitten and Pillkoppen, proves the theory, that main Iron Age settlement activity began here not as the earliest at the beginning of the $13^{\text {th }}$ century and was caused by the war of Prussians with Teutonic knights and new political realities of German colonisation, which made Curonian Spit an important war and trade road, connecting Sambian peninsula with newly established castle of Memel-Burg. 
I priedas. Lentelès

\section{I.1. Kuršių nerijos ir artimiausių teritorijų XII/XIII-XV a. archeologiniai paminklai ir atsitiktiniai radiniai \\ (Pagal. CEN, RGA, Engel 1931b; Širouchov 2012š). 1 pav.}

\begin{tabular}{|c|c|c|c|c|}
\hline Nr. & \begin{tabular}{|l|} 
Paminklo \\
pavadinimas
\end{tabular} & $\begin{array}{l}\text { Paminklo } \\
\text { rūšis }\end{array}$ & $\begin{array}{l}\text { Laikotarpis } \\
\text { (amž.) }\end{array}$ & Radiniai \\
\hline 1. & Alt-Negeln (Nagliai) & - & XI-XIV a. (?) & Svarstyklių fr. (ats. rad.) \\
\hline 2. & Korallen-Berg & Gyvenvietė & $\begin{array}{l}\text { XII(?)-XIII/ } \\
\text { XIV a. }\end{array}$ & $\begin{array}{l}\text { Nurodyto laiko- } \\
\text { tarpio radiniai }\end{array}$ \\
\hline 3. & Kuršių nerija & - & XI-XIV a. (?) & 3 svareliai (ats. rad.) \\
\hline 4. & Lattenwalde & Kapinynas & XIII-XV a. & $\begin{array}{l}\text { Nurodyto laiko- } \\
\text { tarpio radiniai }\end{array}$ \\
\hline 5. & Pillkopen & - & XII-XIV a. (?) & $\begin{array}{l}\text { Apyrankè gyvuliniais } \\
\text { galais (ats. rad.) }\end{array}$ \\
\hline 6. & $\begin{array}{l}\text { Pillkoppen, } \\
\text { Caspalagen berg }\end{array}$ & Gyvenvietė & XIII a. p. - XV a. & pasaginè segè (ats.rad:. \\
\hline 7. & Pillkopen, Lepas kalns & Gyvenvietė & XIII a. p. - XV a. & $\begin{array}{l}\text { Ordino laikotarpio } \\
\text { keraminių indų šukos } \\
\text { ir plytų skeveldros }\end{array}$ \\
\hline 8. & $\begin{array}{l}\text { Pillkopen, Hirschbu- } \\
\text { denberg }\end{array}$ & - & XIII-XV a. (?) & Bronzinès sagtys \\
\hline 9. & Pillkoppen-Neuhaus & $\begin{array}{l}\text { Ittvirtinimas } \\
\text { (pilis?) }\end{array}$ & Issteigtas $1333 \mathrm{~m}$. & - \\
\hline 10. & Pilkoppen-Rossiten & - & XIII-XV a. (?) & Atsitiktiniai radiniai \\
\hline 11. & Pilkoppen-Preil(a) & - & XIII-XV a. (?) & Pasaginès segès, ats. rad. \\
\hline 12. & Rossiten & Pilis & $1300 / 1330 \mathrm{~m}$. & - \\
\hline 13. & Rossiten & Kapinynas & $\begin{array}{l}\text { XII/XIII-XIV/ } \\
\text { XV a. (?) }\end{array}$ & $\begin{array}{l}\text { Pasaginė segé gy- } \\
\text { vuliniais galais }\end{array}$ \\
\hline 14. & Stangenwalde (Kuncai) & Kapinynas & XIII-XV a. & $\begin{array}{l}\text { Nurodyto laiko- } \\
\text { tarpio radiniai }\end{array}$ \\
\hline 15. & Ventès ragas & Pilis (?) & İsteigta $1360 \mathrm{~m}$. & - \\
\hline 16. & $\begin{array}{l}\text { Klaipèda (Me- } \\
\text { mel-Burg) }\end{array}$ & Pilis & İsteigta $1253 \mathrm{~m}$. & $\begin{array}{l}\text { XIII/XIV-XV a. } \\
\text { papuošalai }\end{array}$ \\
\hline 17. & Žardè-Laistai & $\begin{array}{l}\text { Gyvenviečiuc } \\
\text { kompleksas }\end{array}$ & X/XI-XIII a. & $\begin{array}{l}\text { Nurodyto laiko- } \\
\text { tarpio radiniai }\end{array}$ \\
\hline 18. & $\begin{array}{l}\text { Badužiai, Janiš- } \\
\text { kės, Laistai }\end{array}$ & Kapinynai & X/XI-XIII a. & $\begin{array}{l}\text { Nurodyto laiko- } \\
\text { tarpio radiniai }\end{array}$ \\
\hline 19. & Laptau & Pilis & Isteigta $1258 \mathrm{~m}$. & - \\
\hline 20. & $\begin{array}{l}\text { Kaup-Wiskiau- } \\
\text { ten-Wosegau }\end{array}$ & $\begin{array}{l}\text { Gyvenviečiu } \\
\text { kompleksas }\end{array}$ & X/XI-XIII a. & $\begin{array}{l}\text { Nurodyto laiko- } \\
\text { tarpio radiniai }\end{array}$ \\
\hline 21. & $\begin{array}{l}\text { K1. Kaup, Mülsen, } \\
\text { Bludau, Laptau, Schul- } \\
\text { stein, Klincovka-1 }\end{array}$ & Kapinynai & X/XI-XIII a. & $\begin{array}{l}\text { Nurodyto laiko- } \\
\text { tarpio radiniai }\end{array}$ \\
\hline
\end{tabular}




\section{I.2. Stangenwalde kapinyno ịkapių būdingumas prūsų ir pietų kuršių etnosams XIII-XV a. ${ }^{1}$}

\begin{tabular}{|c|c|c|c|}
\hline Nr. & İkapių tipai & Prūsai & Kuršiai \\
\hline 1. & $\begin{array}{l}\text { Pasaginès segès (keturkampiais, } \\
\text { aguoniniais, gyvuliniais galais) }\end{array}$ & + & + \\
\hline 2. & Pasaginès gyvulinès segès vytu (pintu) lankeliu & + & - \\
\hline 3. & Pasaginès segès žvaigždiniais sujungtais galais & + & + \\
\hline 4. & Skardinès segès & + & - \\
\hline 5. & Segès su lotyniškais užrašais & + & + \\
\hline 6. & Vytinės-spiralinės antkaklès XIII a. & + & +- \\
\hline 7. & Juostinès apyrankès & + & + \\
\hline 8. & Spiralinės apyrankès & +- & + \\
\hline 9. & Žiedai (pinti, juostiniai) & + & + \\
\hline 10. & Ginklai & + & + \\
\hline 11. & Uždari skiltuvai & + & + \\
\hline 12. & Puodai kapuose & + & +- \\
\hline 13. & Lokio nago kabučiai & + & +- \\
\hline 14. & Smiltainio verpstukai & - & + \\
\hline 15. & Geriamieji ragai & +- & + \\
\hline 16. & Raktai „E-D“ tipų (pagal Kolčiną) & + & - \\
\hline 17. & Sidabru plakiruoti „,riterių“ diržai (apkalai) & + & - \\
\hline 18. & Svarstyklès-svareliai XIII a. kapuose & + & - \\
\hline 19. & Diržo kabliukai & + & - \\
\hline \multicolumn{2}{|r|}{ Balai } & 17 & 11,5 \\
\hline
\end{tabular}

1 Kiekvienas „,+“ lentelèje reiškia tam tikro dirbinio būdingumą prūsų ar kuršių etnosams, arba 1 balą, ,,+-“ - kad dirbiniai aptinkami etnoso teritorijoje, bet retai ir apskritai nèra būdingi ( 0,5 balo), ir „,-“ atitinkamai reiškia, kad dirbinys nežinomas etnoso teritorijoje (0 balo). 


\section{I.3. Korallen-Bergo XII-XIV/XV a. dirbiniai} prūsų ir kuršių kultūros kontekste

\begin{tabular}{|c|c|c|c|}
\hline Nr. & Ilkapių tipai & Prūsai & Kuršiai \\
\hline 1. & $\begin{array}{l}\text { Pasaginės segès aguoniniais } \\
\text { ir cilindriniais galais }\end{array}$ & + & + \\
\hline 2. & Plokštinė kryžminè segė & + & + \\
\hline 3. & Ivijinis žiedas & + & + \\
\hline 4. & Bronzinis karolis & + & + \\
\hline 5. & Kaulinès šukos (kapuose) & + & +- \\
\hline 6. & $\begin{array}{l}\text { Žiesti puodai (V. Žulkaus } \\
\text { B1:b, B:2b tipų ir kt.) }\end{array}$ & + & + \\
\hline 7. & Šiferinis verpstukas & + & +- \\
\hline 8. & Skiltuvas atriestais galais & +- & + \\
\hline 9. & Žeberklinis ietigalis & + & + \\
\hline 10. & Laivu kniedès & + & + \\
\hline & Balai & 9,5 & 9 \\
\hline
\end{tabular}

